Human Mutation

WILEY

\title{
Genetic classification and mutational spectrum of more than 600 patients with a Zellweger syndrome spectrum disorder
}

\begin{tabular}{|r|l|}
\hline Journal: & Human Mutation \\
\hline Manuscript ID: & humu-2010-0170.R1 \\
\hline Wutey - Manuscript type: & Research Article \\
\hline Date Submitted by the & 30 -Aug-2010 \\
\hline Complete List of Authors: & $\begin{array}{l}\text { Ebberink, Merel; Academic Medical Centre, University of } \\
\text { Amsterdam, Laboratoy Genetic Metabolic Diseases } \\
\text { Mooyer, Petra; Academic Medical Centre, University of Amsterdam, } \\
\text { Laboratoy Genetic Metabolic Diseases, Department of Clinical } \\
\text { Chemistry } \\
\text { Gootjes, Jeannette; Academic Medical Centre, University of } \\
\text { Amsterdam, Laboratoy Genetic Metabolic Diseases } \\
\text { Koster, Janet; Academic Medical Centre, University of Amsterdam, } \\
\text { Laboratoy Genetic Metabolic Diseases } \\
\text { Wanders, Ronald; Academic Medical Centre, University of } \\
\text { Amsterdam, Laboratoy Genetic Metabolic Diseases, Department of } \\
\text { Clinical Chemistry; Academic Medical Centre, Clinical Chemistry, } \\
\text { Lab Genetic Metabolic Diseases, room F0-224, } \\
\text { Waterham, Hans; Academic Medical Center, Lab. Genet. Metab. Dis. } \\
\text { (F0-222) }\end{array}$ \\
\hline Key Words: & $\begin{array}{l}\text { Zellweger Syndrome, PEX genes, PEX genes, peroxisome, } \\
\text { biogenesis }\end{array}$ \\
\hline
\end{tabular}


Genetic classification and mutational spectrum of more than 600 patients with a

Zellweger syndrome spectrum disorder

Merel S. Ebberink, Petra A.W. Mooijer, Jeannette Gootjes, Janet Koster, Ronald J.A.

Wanders, Hans R. Waterham

Laboratory Genetic Metabolic Diseases, Academic Medical Centre at the University of Amsterdam, Amsterdam, the Netherlands.

Address for correspondence:

Hans R. Waterham, PhD

Laboratory Genetic Metabolic Diseases (F0-222)

Academic Medical Centre, University of Amsterdam

P.O. Box 22700, 1100 DE Amsterdam

The Netherlands

Tel: +31205665958

Fax: +31206962596

Email: h.r.waterham@amc.uva.nl 


\section{Key words}

Zellweger Syndrome, PEX genes, genetic complementation, peroxisome, biogenesis 


\section{Introduction}

Peroxisome biogenesis disorders (MIM 601539) include the Zellweger syndrome spectrum (ZSS) disorders and Rhizomelic Chondrodysplasia Punctata type I (Weller et al., 2003). The latter is caused by mutations in the PEX7 gene, encoding a cytosolic receptor involved in the import of a small subset of peroxisomal matrix proteins (Braverman et al., 2002; Motley et al., 2002). The ZSS disorders include the Zellweger syndrome (ZS, MIM 214100), neonatal adrenoleukodystrophy (NALD, MIM 202370) and infantile Refsum disease (IRD, MIM 266510), which represent a spectrum of disease severity with ZS being the most, and IRD the least severe disorder.

ZSS disorders are autosomal recessive disorders and can be caused by a defect in any of at least 12 different $P E X$ genes (Steinberg et al., 2006). These PEX genes encode proteins called peroxins that are involved in various stages of peroxisomal protein import and/or the biogenesis of peroxisomes. Severe defects in one of these $P E X$ genes result in a complete absence of functional peroxisomes as observed in the Zellweger Syndrome phenotype. The NALD or IRD phenotypes are often associated with residual peroxisomal functions and/or partial functional peroxisomes (i.e. peroxisomal mosaicism (Wanders and Waterham, 2006; Weller et al., 2003)).

Many human PEX genes have been identified on the basis of sequence similarity with yeast $P E X$ genes identified by functional complementation of peroxisome-deficient yeast mutants. At present more than 30 different peroxins have been identified in different yeast species, including Saccharomyces cerevisiae and Yarrowia lipolytica. The peroxins are involved in different peroxisomal processes, such as the formation of peroxisomal membranes, peroxisomal growth, fission and proliferation, and import of matrix proteins (Platta and Erdmann, 2007). Of these yeast peroxins, 19 have been implicated in peroxisome protein import and biogenesis, whereas in humans, so far only 13 peroxins have been 
identified that are required for these processes. To study whether human peroxisome

biogenesis requires the action of additional peroxins, we set out to assign primary skin

fibroblasts from patients diagnosed with a ZSS disorder to different genetic complementation

groups. Following the complementation analysis, we performed mutation analysis of the

respective $P E X$ genes in a majority of cell lines. We here report the results of our genetic

complementation studies in more than 600 cell lines from patients with a Zellweger syndrome

Deleted: most of the

Deleted: an overview

Deleted: patient

spectrum disorder. In addition, we provide an overview of all mutations we identified in these

patient cell lines, completed with previously reported mutations in the respective PEX genes. 


\section{Methods \\ Cell lines}

For this study, we used 613 independent primary skin fibroblast cell lines from non-related patients that had been sent to our laboratory since 1985 for diagnostic evaluation and which were diagnosed with a ZSS disorder. The diagnosis is based on metabolite analysis in plasma, which ideally involves analysis of very long chain fatty acids (VLCFAs), bile acid intermediates, phytanic acid, pristanic acid, pipecolic acid and plasmalogens, and/or detailed studies in fibroblasts, including VLCFA analysis, C26:0 and pristanic acid $\beta$-oxidation, phytanic acid $\alpha$-oxidation and dihydroxyacetonephosphate acyltransferase (DHAPAT) activity analysis, and the absence of peroxisomes assessed by on catalase immunofluorescence (IF) microscopy (Wanders and Waterham, 2005). The cell lines were cultured in DMEM medium (Gibco, Invitrogen) supplemented with 10\% fetal bovine serum (FBS, Bio-Whittaker), $100 \mathrm{U} / \mathrm{ml}$ penicillin, 100 $\mathrm{g} / \mathrm{ml}$ streptomycin and $25 \mathrm{mM}$ Hepes buffer with L-glutamine in a humidified atmosphere of $5 \% \mathrm{CO}_{2}$ and at $37^{\circ} \mathrm{C}$. In accordance to the institutional guidelines and the Dutch Code of Conduct, identifiable clinical and personal data from the patients were not available for this study.

\section{Genetic complementation assays}

To assign cell lines to genetic complementation groups, we used a previously described polyethylene glycol (PEG)- mediated cell fusion assay (Brul et al., 1988) and a PEX cDNA transfection assay, specifically developed for this purpose. In the latter assay, ZSS cell lines are co-transfected separately with one of the 12 different $P E X$ cDNAs subcloned in the pcDNA3 expression vector (Invitrogen, Carlsbad, CA) and an eGFP-SKL vector (Waterham et al., 2007). The eGFP-SKL vector expresses eGFP tagged with the peroxisomal targeting signal -SKL, which allows immediate visual detection of peroxisomes when present. The 
transfections were performed with the NHDF Nucleofector Kit (Amaxa, Cologne, Germany) and the Nucleofector Device (Amaxa, Cologne, Germany) using the standard program U-23, which in our hands results in high transfection efficiencies ranging from $70-80 \%$ for primary skin fibroblasts. We performed the transfections of cell lines in three subsequent series based on the estimated frequency of the different PEX gene defects. In the first series, we transfected cell lines separately with PEX1, PEX6 and PEX12. Cell lines that were not functionally complemented were then transfected separately with PEX2, PEX10 and PEX26 and finally with PEX5, PEX13 and PEX14. Transfection with PEX3, PEX16 and PEX19 was

Deleted: used the following transfection order of PEX expression vectors based on the estimated frequency of the different $P E X$ gene defects: 1)

Deleted: ; 2)

Deleted: ; 3)

performed when the patient fibroblasts showed no peroxisomal membrane remnants based on immunofluorescence microscopy (van Grunsven et al., 1999) with antibodies against ALDP (Euromedex, France, Souffelweyersheim), a peroxisomal membrane protein. Cells were examined by means of fluorescence microscopy 48 to 72 hours after transfection to determine the subcellular localization of the peroxisomal reporter protein eGFP-SKL (see also figure 1).

\section{Mutation analysis}

Mutation analysis was performed by either sequencing all exons plus flanking intronic sequences of the $P E X$ genes amplified by PCR from genomic DNA or by sequencing PEX cDNAs prepared from total RNA fractions. Genomic DNA was isolated from skin fibroblasts using the NucleoSpin Tissue genomic DNA purification kit (Macherey-Nagel, Germany, Düren). Total RNA was isolated from skin fibroblasts using Trizol (Invitrogen, Carlsbad, CA) extraction, after which cDNA was prepared using a first strand cDNA synthesis kit for RTPCR (Roche, Mannheim, Germany). All forward and reverse primers (Supp tables S1-11) were tagged with a -21M13 (5-'TGTAAAACGACGGCCAGT-3') sequence or M13rev (5'CAGGAAACAGCTATGACC-3') sequence, respectively. PCR fragments were sequenced in two directions using '-21M13' and 'M13rev' primers by means of BigDye Terminator v1.1 
Cycle Sequencing Kits (Applied Biosystems, Foster City, CA, USA) and analyzed on an Applied Biosystems 377A automated DNA sequencer, following the manufacturer's protocol (Applied Biosystems, Foster City, CA, USA).

Mutation analysis of PEXI (GenBank accession number NM_000466.2) was performed by sequencing the coding region of the PEXI cDNA and/ or exons amplified from gDNA or by RFLP analysis to identify the frequently occurring c. $2528 \mathrm{G}>\mathrm{A}$ mutation. The RFLP analysis involves PCR amplification using a specific primer set (see Supp Table S1) of a 130-bp genomic DNA fragment encompassing the c.2528G/A nuctleotide, followed by restriction analysis with $C l a \mathrm{I}$. The c. $2528 \mathrm{G}>\mathrm{A}$ mutation creates a restriction recognition site for $\mathrm{Cla \textrm {I }}$ and thus can be screened for by RFLP analysis. Mutations in the PEX2 gene were identified by sequencing the coding exon 4 from gDNA (NM_000318.2). The PEX3 (NM_003630.2) gene was analyzed by sequencing of the coding region of the PEX3 cDNA, Mutation analysis of PEX5L (X84899), PEX10 (NM_002617.3), PEX12 (NM_000286.2), PEX13 (NM_002618.2), PEX14 (NM_004565.2), PEX16 (NM_004813.2), PEX19 (NM_002857.2) and PEX26 (NM_017929.4) were performed by sequencing of all exons plus flanking intronic sequences amplified from gDNA. Sequences were compared with the indicated reference sequences with nucleotide numbering starting at the first adenine of the translation initiation codon ATG. The possible consequences of missense mutations were analyzed using the Polyphen prediction software (http://genetics.bwh.harvard.edu/pph/)

Deleted: (NM_003630)

Deleted: 1538
Deleted: and

Deleted: p.G843D 


\section{Results and Discussion \\ Genetic complementation}

Initially, we used a previously reported cell fusion complementation assay (Brul et al., 1988).

Because this assay is rather laborious, we developed a more rapid and direct complementation assay taking advantage of the known identities of the 12 human PEX genes that can cause a

ZSS disorder (for principle see figure 1). The PEX cDNA transfection assay worked very well for cell lines displaying complete peroxisome deficiencies, and for cell lines displaying different degrees of peroxisomal mosaicism that are sensitive to culturing at $40^{\circ} \mathrm{C}$, which exacerbates the defect in peroxisome biogenesis (Gootjes et al., 2004b). We assigned 613 different ZSS cell lines to genetic complementation groups (Table 1). The results give a representative overview of the spectrum of $P E X$ gene defects among ZSS disorders with PEX1 (MIM602136), PEX6 (MIM601498) and PEX12 (MIM601758) defects being the most common. Although we received ZSS cell lines from different parts of the world, they

predominantly ( $>90 \%)$ are from Western European origin and thus the spectrum of PEX gene defects primarily relates to the Western European population.

Deleted: of Caucasian origin Deleted: Caucasian race

Somewhat unexpected, all the analyzed ZSS cell lines could be assigned to one of the known genetic complementation groups and no novel complementation group was identified. In a recent study where 90 cell lines were assigned to genetic complementation groups using a similar approach also no novel complementation groups were identified (Krause et al., 2009). This suggests that, in contrast to yeast where 19 different $P E X$ genes have been implicated, peroxisome biogenesis in humans would only require 12 PEX genes. However, it should be emphasized that to be suitable for genetic complementation testing, cell lines need to display a complete peroxisome deficiency in the majority of cells. It therefore remains possible that defects in other putative human PEX genes cannot be identified by this approach, because they don't result in peroxisome deficiency or perhaps lead to different clinical presentations, 
1

2

3

4

5

6

7

8

9

10

as recently exemplified by a very distinct peroxisomal and mitochondrial fission defect due to a dominant negative mutation in the DLPl gene (Waterham et al., 2007). In addition, defects in certain PEX genes may also be without consequences due to gene redundancy. For example, recently 3 human proteins have been reported with a similar function as the yeast PEX4 gene, which is associated with complete peroxisome deficiency in yeast (Grou et al., 2008). Considering that these proteins are encoded by different genes and each can promote Deleted: , appears to have 3 human

Deleted: ortholoques the ubiquitination of PEX5 (MIM600414) on its own, it seems unlikely that a defect in one of these proteins will cause a peroxisomal disorder (Grou et al., 2008). Finally, although we consider this unlikely, we cannot exclude the possibility that a defect in certain unannotated $\underline{P E X}$ genes may be embryonic lethal and thus will not be diagnosed.

\section{Mutation analysis}

After the assignment of patient cell lines to genetic complementation groups, we performed

mutation analysis of the respective PEX genes in 393 of the cell lines. For most genes all coding exons plus flanking intron sequences were analysed by sequencing. In principle, this $\underline{\text { method will identify all missense and nonsense mutations, small deletions, small duplications }}$ and small insertions located in the analysed fragments. However, the presence of large, heterozygous deletions or duplications, or pathogenic mutations located outside the analysed fragments cannot be excluded. The reported mutations are assumed to be pathogenic for the following reasons: 1) They are the only sequence variants identified in the coding regions or flanking intronic sequences of a given $P E X$ gene that was demonstrated to be defective by the fact that peroxisome biogenesis in the corresponding cell line is restored after transfection with the respective $P E X$ cDNA (i.e. a functional assay). 2) The sequence variants are not listed in the SNP database or encountered in more than 100 control chromosomes. 
PEXI is the most affected gene among patients with a ZSS disorder. It encodes a protein belonging to the AAA ATPase protein family (ATPases Associated with various cellular Activities) and contains two ATP-binding folds. Table 2 lists all mutations identified in the cell lines we analyzed completed with mutations reported in literature. Among these mutations a few common mutations have been identified (Maxwell et al., 2005). The most common mutation in PEXI is a missense mutation in the second ATP-binding domain (c.2528G >A) leading to p.G843D. This mutation reduces the binding between PEX1 and PEX6 and is known for its temperature sensitivity, meaning that when fibroblasts of patients homozygous for $\mathrm{G} 843 \mathrm{D}$ are cultured at $30^{\circ} \mathrm{C}$, they regain the ability to import catalase and other peroxisomal matrix proteins, as well as the various peroxisomal metabolic functions (Imamura et al., 1998a; Maxwell et al., 2005). Patients homozygous for the G843D mutation usually present with the milder IRD phenotype. Cells of these patients often display peroxisomal mosaicism at $37^{\circ} \mathrm{C}$, but a complete peroxisome deficiency when cultured at $40^{\circ} \mathrm{C}$. The second most common mutation in PEX1 is c.2079_2098insT, which results in a frame shift predicted to cause a truncated PEX1 protein (Collins and Gould, 1999), although Northern blot analysis showed that this mutation results in low steady state PEX1 mRNA levels (Maxwell et al., 2005). Patients homozygous for this mutation are affected with the severe ZS phenotype. The c.2926delA mutation is the third most common mutation in PEX1; this mutation leads to a frame shift. When combined with previously reported PEXI mutations, a total of 88 different mutations have now been identified in the PEXI gene, of which 34 have not been reported previously. In two cell lines we found three heterozygous mutations after sequencing gDNA (Table 1). In the first cell line the following 3 heterozygous mutations were found, p.T526A, p.911_912delCT and p.1885_1886delGT, of which the last $\underline{\text { two have been reported as pathogenic in literature. The consequence of the p.T526A mutation }}$ is unclear, but the threonine at position is a conserved amino acid in Pan troglodytes 
(chimpanzee), Canis familiaris (dog) and Gallus gallus domesticus (chicken) and the software program Polyphen predicts this amino acid substitution as possibly damaging. In the second cell line, the heterozygous p.V336A, p.S555P and p.R949W missense mutations all affect well conserved amino acids and, according to Polyphen, are predicted to be benign, possibly damaging and probably damaging, respectively, suggesting that p.V336A may be a rare sequence variation. All the novel identified missense mutations are not listed in the SNP database, have not been detected in more than 100 control chromosomes and in fact all affect (well) conserved amino acids. In addition, Polyphen predicts these amino acid substitutions as either possibly damaging or probably damaging.

The PEX2 (MIM170993) gene was the first gene reported to be mutated in ZSS patients. PEX2 is an integral membrane protein with two transmembrane domains and a zincbinding motif, probably involved in the poly-ubiquitination of the peroxisomal import receptor PEX5 (Platta et al., 2009). The PEX2 gene contains four exons, but the entire coding region is included in exon 4. One mutation in the PEX2 gene (c.355C >T) was found to be associated with temperature sensitivity: cells cultured at $30^{\circ} \mathrm{C}$ show partial catalase import (Imamura et al., 1998b). The patient fibroblasts homozygous for the c.669G $>$ A mutation displayed a mosaic peroxisomal pattern, characterized by import competency of catalase in $30 \%$ of the cells (Gootjes et al., 2003; Gootjes et al., 2004a). In 3 different cell lines, sequence analysis of exon 4 identified only one heterozygous mutation (table 1). We did not analyze the remaining exons, promoter sequence or PEX2 cDNA of these cell lines. In this study, six novel mutations have been identified, making a total of $1 \underline{1}$ different mutations currently identified in the PEX2 gene (table 3). Two novel missense mutation are identified which are not listed in the SNP database, and both affect (well) conserved amino acids. In addition, Polyphen predicts these amino acid substitutions as probably damaging. 
PEX3 (MIM603164) is an integral membrane protein with two putative membranespanning domains. The exact function of PEX3 is unclear, but it has been assumed that PEX3 plays a role in insertion of peroxisomal membrane proteins into the peroxisomal membrane based on the absence of peroxisomal ghosts in cell lines with a defect in PEX3 (Ghaedi et al., 2000; Muntau et al., 2000). In total, six different mutations in PEX3 were identified of which four have been reported previously (table 4).

PEX5 is a protein with seven di-aromatic pentapeptide repeats $(\mathrm{WxxxF} / \mathrm{Y})$ essential for docking to the peroxisomal membrane and for binding to either PEX13 (MIM601789) or PEX14 (MIM6017912, (Saidowsky et al., 2001; Weller et al., 2003), and with seven tetrapeptide repeats (TPRs) to mediate the interaction with the PTS1 sequence. In humans, two functional protein variants of PEX5 are produced as a result of alternative splicing of the PEX5 mRNA. The longest variant, PEX5L, contains an additional 111 bp encoding 37 amino acids, due to alternative splicing of exon 7 (Dodt et al., 2001). The shorter protein, PEX5S, has been reported to be exclusively involved in peroxisomal PTS1 protein import, whereas PEX5L mediates both PTS1 and PTS2 protein import. We recently published and discussed the mutations we identified in the PEX5 gene elsewhere (Ebberink et al., 2009b). These mutations combined with previously reported mutations are listed in table 5.

The PEX6 gene consists of 17 exons and mutations in the PEX6 gene were found to be scattered throughout the whole gene. PEX6 is also a member of the AAA ATPase family and interacts with PEX1. PEX6 is required for import of peroxisomal matrix proteins and/or vesicle fusion. At present, 77 different mutations in PEX6 gene have been identified, a complete overview of which has been reported very recently and thus will not been shown here (Ebberink et al., 2009a).

PEX10 (MIM602859) is an integral membrane protein and contains two transmembrane domains and a C-terminal zinc-binding motif, similar as PEX2 and PEX12. 
Two mRNA splice forms of PEX10 have been identified, resulting from the use of a different splice acceptor site at the 3'end of intron 3. The longer form accounts for $10 \%$ of the PEX10 mRNA in the cell and appears to be slightly less functional (Warren et al., 2000). Combined with previously reported PEX10 mutations, 25 different mutations have been identified in the PEX10 gene of which nine have not been reported previously (table 6). The six novel $\underline{\text { missense mutations all affect well conserved amino acids and Polyphen predicts these amino }}$ acid substitutions as probably damaging. Sequence analysis of the exons plus flanking intronic sequences of the PEX10 gene identified in one patient only one heterozygous mutation. We did not analyze the PEX10 cDNA in this cell line.

Mutations in the PEX12 gene are the third common cause of a ZSS disorder: 9\% of our patients group has mutations in PEX12. PEX12 is one of the RING (abbreviation for really interesting new gene) finger proteins; it contains two transmembrane domains and a Cterminal zinc-binding motif. All 34 identified PEX12 mutations are listed in table 7, including 8 that have not been reported before. The pS320F mutation $(\mathrm{c} .959 \mathrm{C}>\mathrm{T})$ is the most common PEX12 mutation and is located in the zinc-binding domain. Patients homozygous for this mutation present with an atypical biochemical phenotype in skin fibroblasts: the peroxisomal parameters are mostly normal to slightly abnormal. The mutation causes a temperaturesensitive phenotype: when cultured at $30^{\circ} \mathrm{C}$, all cells contain catalase import competent peroxisomes, when cultured at $37^{\circ} \mathrm{C}$ only, $70 \%$ of the cells contain catalase-positive peroxisomes and when cultured at $40^{\circ} \mathrm{C}$ none of the cells contain catalase-positive peroxisomes (Gootjes et al., 2004c). We identified two novel missense mutations both affecting well conserved amino acids and Polyphen predicts these amino acid substitutions as probably damaging.

PEX13 is a peroxisomal integral membrane protein with two putative membrane domains. The C-terminus contains an SH3 domain, which binds to pentapeptide repeats 2-4 of 
PEX5. The N-terminal part of yeast PEX13 interacts with PEX7. Table 8 lists ten different PEX13 mutations of which six have been reported before. The I326T mutation causes a temperature-sensitive biochemical phenotype in fibroblasts: peroxisomes still import residual levels of PTS1 and PTS2 proteins at $37^{\circ} \mathrm{C}$ but not at elevated temperature (Liu et al., 1999; Shimozawa et al., 1999a). One novel missense mutation was identified which affects a well conserved amino acid and is probably damaging according to Polyphen.

The PEX14 gene encodes a peroxisomal membrane protein that was initially identified as a peroxisomal docking factor for the PTS1 receptor PEX5 via binding to the aminoterminal WxxxF/Y motifs of PEX5. More recently, it was proposed that PEX14 is also the site from which PEX5 leaves the peroxisomal compartment (Azevedo and Schliebs, 2006). A mutation in PEX14 is the least common cause of ZZS disorder. Three different mutations have now been identified in the PEX14 gene of which 1 has not been reported previously (table 9).

The PEX16 (MIM603360) gene encodes an integral peroxisomal membrane protein involved in peroxisomal membrane assembly. Two different groups of PEX16-defective patients have been reported; patients with a severe clinical presentation of which the fibroblasts displayed a defect in import of peroxisomal matrix and membrane proteins, resulting in a total absence of peroxisomal remnants (Honsho et al., 1998; Shimozawa et al., 2002), and very recently, several patients with a relatively mild clinical phenotype of which the fibroblasts showed enlarged, import-competent peroxisomes (Ebberink et al., 2010), In total eight different mutations have been identified in the PEX16 gene of which one has not been reported previously (table 10).

The PEX19 (MIM600279) gene encodes a mainly cytosolic protein that binds many peroxisomal membrane proteins, suggesting that PEX19 functions as a peroxisomal receptor

for peroxisomal membrane proteins (Sacksteder et al., 2000). The patients with a defect in 
PEX19 presented with a severe ZS phenotype and the fibroblasts displayed the absence of peroxisomal ghosts (Matsuzono et al., 1999). Table 11 lists three different PEX19 mutations of which two have not been reported before.

PEX26 (MIM608666) is a membrane protein with one putative membrane-spanning domain. Human PEX26 is the ortholoque of yeast PEX15. Some of the reported mutations were found to lead to temperature-sensitive biochemical phenotype (Matsumoto et al., 2003b; Matsumoto et al., 2003a). Combined with previously reported PEX26 mutations, 22 different mutations have now been identified in the PEX26 gene of which three have not been reported previously (table 12).

\section{Conclusions}

In summary, we developed an efficient genetic complementation assay, which allows rapid identification of the defective $P E X$ gene in fibroblast cell lines of ZSS patients. This assay has been incuded in our diagnostic work up of patients diagnosed with a ZSS disorder, followed by sequence analysis of the defective $P E X$ gene. After analysis of 613 independent cell lines, we did not detect cell lines with a novel defective $P E X$ gene suggesting that only mutations in one of the currently known PEX genes leads to complete peroxisome deficiency and a Zellweger Syndrome-like presentation.

\section{Acknowledgements}

We thank to Dr. S.J. Gould for the gift of PEX pcDNA3 plasmids, J. Haasjes, W. Oostheim, M. de Gijsel and R.A. Jibodh for their assistance in different parts of this study and Dr. S. Ferdinandusse for critical reading of the manuscript. This study was supported by a grant from the "Prinses Beatrix Fonds" (MAR 03_0216) and by the FP6 European Union Project 
"peroxisomes" (LSHG-CT-2004512018). We gratefully acknowledge all doctors and medical specialists who referred patient material to our laboratory. 


\section{References}

Al-Dirbashi OY, Shaheen R, Al-Sayed M, Al-Dosari M, Makhseed N, Abu SL, Santa T, Meyer BF, Shimozawa N, Alkuraya FS. 2009. Zellweger syndrome caused by PEX13 deficiency: report of two novel mutations. Am J Med Genet A 149A:1219-1223.

Azevedo JE, Schliebs W. 2006. Pex14p, more than just a docking protein. Biochim Biophys Acta 1763:1574-1584.

Braverman N, Chen L, Lin P, Obie C, Steel G, Douglas P, Chakraborty PK, Clarke JT, Boneh A, Moser A, Moser H, Valle D. 2002. Mutation analysis of PEX7 in 60 probands with rhizomelic chondrodysplasia punctata and functional correlations of genotype with phenotype. Hum Mutat 20:284-297.

Brul S, Westerveld A, Strijland A, Wanders RJ, Schram AW, Heymans HS, Schutgens RB, van den BH, Tager JM. 1988. Genetic heterogeneity in the cerebrohepatorenal (Zellweger) syndrome and other inherited disorders with a generalized impairment of peroxisomal functions. A study using complementation analysis. J Clin Invest 81:1710-1715.

Chang CC, Gould SJ. 1998. Phenotype-genotype relationships in complementation group 3 of the peroxisome-biogenesis disorders. Am J Hum Genet 63:1294-1306.

Chang CC, Warren DS, Sacksteder KA, Gould SJ. 1999. PEX12 interacts with PEX5 and PEX10 and acts downstream of receptor docking in peroxisomal matrix protein import. J Cell Biol 147:761-774.

Collins CS, Gould SJ. 1999. Identification of a common PEX1 mutation in Zellweger syndrome. Hum Mutat 14:45-53.

Dodt G, Braverman N, Wong C, Moser A, Moser HW, Watkins P, Valle D, Gould SJ. 1995. Mutations in the PTS1 receptor gene, PXR1, define complementation group 2 of the peroxisome biogenesis disorders. Nat Genet 9:115-125.

Dodt G, Warren D, Becker E, Rehling P, Gould SJ. 2001. Domain mapping of human PEX5 reveals functional and structural similarities to Saccharomyces cerevisiae Pex18p and Pex21p. J Biol Chem 276:41769-41781.

Dursun A, Gucer S, Ebberink MS, Yigit S, Wanders RJ, Waterham HR. 2009. Zellweger syndrome with unusual findings: non-immune hydrops fetalis, dermal erythropoiesis and hypoplastic toe nails. J Inherit Metab Dis.

Ebberink MS, Csanyi B, Chong WK, Denis S, Sharp P, Mooijer PA, Dekker CJ, Spooner C, Ngu LH, De SC, Wanders RJ, Fietz MJ, Clayton PT, Waterham HR, Ferdinandusse S. 2010. Identification of an unusual variant peroxisome biogenesis disorder caused by mutations in the PEX16 gene. J Med Genet 47:608-615.

Ebberink MS, Kofster J, Wanders RJ, Waterham HR. 2009a. Spectrum of PEX6 mutations in Zellweger syndrome spectrum patients. Hum Mutat. 
Ebberink MS, Mooyer PA, Koster J, Dekker CJ, Eyskens FJ, Dionisi-Vici C, Clayton PT, Barth PG, Wanders RJ, Waterham HR. 2009b. Genotype-phenotype correlation in PEX5-deficient peroxisome biogenesis defective cell lines. Hum Mutat 30:93-98.

Gartner J, Preuss N, Brosius U, Biermanns M. 1999. Mutations in PEX1 in peroxisome biogenesis disorders: G843D and a mild clinical phenotype. J Inherit Metab Dis 22:311-313.

Ghaedi K, Honsho M, Shimozawa N, Suzuki Y, Kondo N, Fujiki Y. 2000. PEX3 is the causal gene responsible for peroxisome membrane assembly-defective Zellweger syndrome of complementation group G. Am J Hum Genet 67:976-981.

Gootjes J, Elpeleg O, Eyskens F, Mandel H, Mitanchez D, Shimozawa N, Suzuki Y, Waterham HR, Wanders RJ. 2004a. Novel mutations in the PEX2 gene of four unrelated patients with a peroxisome biogenesis disorder. Pediatr Res 55:431-436.

Gootjes J, Mandel H, Mooijer PA, Roels F, Waterham HR, Wanders RJ. 2003. Resolution of the molecular defect in a patient with peroxisomal mosaicism in the liver. Adv Exp Med Biol 544:107-111.

Gootjes J, Schmohl F, Mooijer PA, Dekker C, Mandel H, Topcu M, Huemer M, Von SM, Marquardt T, Smeitink JA, Waterham HR, Wanders RJ. 2004b. Identification of the molecular defect in patients with peroxisomal mosaicism using a novel method involving culturing of cells at 40 degrees C: implications for other inborn errors of metabolism. Hum Mutat 24:130-139.

Gootjes J, Schmohl F, Waterham HR, Wanders RJ. 2004c. Novel mutations in the PEX12 gene of patients with a peroxisome biogenesis disorder. Eur J Hum Genet 12:115-120.

Gootjes J, Skovby F, Christensen E, Wanders RJ, Ferdinandusse S. 2004d. Reinvestigation of trihydroxycholestanoic acidemia reveals a peroxisome biogenesis disorder. Neurology 62:2077-2081.

Grou CP, Carvalho AF, Pinto MP, Wiese S, Piechura H, Meyer HE, Warscheid B, SaMiranda C, Azevedo JE. 2008. Members of the E2D (UbcH5) Family Mediate the Ubiquitination of the Conserved Cysteine of Pex5p, the Peroxisomal Import Receptor. J Biol Chem 283:14190-14197.

Honsho M, Tamura S, Shimozawa N, Suzuki Y, Kondo N, Fujiki Y. 1998. Mutation in PEX16 is causal in the peroxisome-deficient Zellweger syndrome of complementation group D. Am J Hum Genet 63:1622-1630.

Huybrechts SJ, Van Veldhoven PP, Hoffman I, Zeevaert R, de VR, Demaerel P, Brams M, Jaeken J, Fransen M, Cassiman D. 2008. Identification of a novel PEX14 mutation in Zellweger syndrome. J Med Genet 45:376-383.

Imamura A, Tamura S, Shimozawa N, Suzuki Y, Zhang Z, Tsukamoto T, Orii T, Kondo N, Osumi T, Fujiki Y. 1998a. Temperature-sensitive mutation in PEX1 moderates the phenotypes of peroxisome deficiency disorders. Hum Mol Genet 7:2089-2094.

Imamura A, Tsukamoto T, Shimozawa N, Suzuki Y, Zhang Z, Imanaka T, Fujiki Y, Orii T, Kondo N, Osumi T. 1998b. Temperature-sensitive phenotypes of peroxisome- 
assembly processes represent the milder forms of human peroxisome-biogenesis disorders. Am J Hum Genet 62:1539-1543.

Krause C, Rosewich H, Gartner J. 2009. Rational diagnostic strategy for Zellweger syndrome spectrum patients. Eur J Hum Genet.

Krause C, Rosewich H, Thanos M, Gartner J. 2006. Identification of novel mutations in PEX2, PEX6, PEX10, PEX12, and PEX13 in Zellweger spectrum patients. Hum Mutat 27:1157.

Liu Y, Bjorkman J, Urquhart A, Wanders RJ, Crane DI, Gould SJ. 1999. PEX13 is mutated in complementation group 13 of the peroxisome-biogenesis disorders. Am J Hum Genet 65:621-634.

Matsumoto N, Tamura S, Fujiki Y. 2003a. The pathogenic peroxin Pex26p recruits the Pex1p-Pex6p AAA ATPase complexes to peroxisomes. Nat Cell Biol 5:454-460.

Matsumoto N, Tamura S, Furuki S, Miyata N, Moser A, Shimozawa N, Moser HW, Suzuki Y, Kondo N, Fujiki Y. 2003b. Mutations in novel peroxin gene PEX26 that cause peroxisome-biogenesis disorders of complementation group 8 provide a genotypephenotype correlation. Am J Hum Genet 73:233-246.

Matsuzono Y, Kinoshita N, Tamura S, Shimozawa N, Hamasaki M, Ghaedi K, Wanders RJ, Suzuki Y, Kondo N, Fujiki Y. 1999. Human PEX19: cDNA cloning by functional complementation, mutation analysis in a patient with Zellweger syndrome, and potential role in peroxisomal membrane assembly. Proc Natl Acad Sci U S A 96:21162121.

Maxwell MA, Allen T, Solly PB, Svingen T, Paton BC, Crane DI. 2002. Novel PEX1 mutations and genotype-phenotype correlations in Australasian peroxisome biogenesis disorder patients. Hum Mutat 20:342-351.

Maxwell MA, Leane PB, Paton BC, Crane DI. 2005. Novel PEX1 coding mutations and 5' UTR regulatory polymorphisms. Hum Mutat 26:279.

Motley AM, Brites P, Gerez L, Hogenhout E, Haasjes J, Benne R, Tabak HF, Wanders RJ, Waterham HR. 2002. Mutational spectrum in the PEX7 gene and functional analysis of mutant alleles in 78 patients with rhizomelic chondrodysplasia punctata type 1. Am J Hum Genet 70:612-624.

Muntau AC, Mayerhofer PU, Paton BC, Kammerer S, Roscher AA. 2000. Defective peroxisome membrane synthesis due to mutations in human PEX3 causes Zellweger syndrome, complementation group G. Am J Hum Genet 67:967-975.

Okumoto K, Fujiki Y. 1997. PEX12 encodes an integral membrane protein of peroxisomes. Nat Genet 17:265-266.

Okumoto K, Itoh R, Shimozawa N, Suzuki Y, Tamura S, Kondo N, Fujiki Y. 1998a. Mutations in PEX10 is the cause of Zellweger peroxisome deficiency syndrome of complementation group B. Hum Mol Genet 7:1399-1405. 
Okumoto K, Shimozawa N, Kawai A, Tamura S, Tsukamoto T, Osumi T, Moser H, Wanders RJ, Suzuki Y, Kondo N, Fujiki Y. 1998b. PEX12, the pathogenic gene of group III Zellweger syndrome: cDNA cloning by functional complementation on a CHO cell mutant, patient analysis, and characterization of PEX12p. Mol Cell Biol 18:43244336.

Platta HW, El MF, Baumer BE, Schlee D, Girzalsky W, Erdmann R. 2009. Pex2 and pex12 function as protein-ubiquitin ligases in peroxisomal protein import. Mol Cell Biol 29:5505-5516.

Platta HW, Erdmann R. 2007. The peroxisomal protein import machinery. FEBS Lett 581:2811-2819.

Portsteffen H, Beyer A, Becker E, Epplen C, Pawlak A, Kunau WH, Dodt G. 1997. Human PEX1 is mutated in complementation group 1 of the peroxisome biogenesis disorders. Nat Genet 17:449-452.

Preuss N, Brosius U, Biermanns M, Muntau AC, Conzelmann E, Gartner J. 2002. PEX1 mutations in complementation group 1 of Zellweger spectrum patients correlate with severity of disease. Pediatr Res 51:706-714.

Regal L, Ebberink MS, Goemans N, Wanders RJ, De ML, Jaeken J, Schrooten M, Van CR, Waterham HR. 2010. Mutations in PEX10 are a cause of autosomal recessive ataxia. Ann Neurol 68:259-263.

Reuber BE, Germain-Lee E, Collins CS, Morrell JC, Ameritunga R, Moser HW, Valle D, Gould SJ. 1997. Mutations in PEX1 are the most common cause of peroxisome biogenesis disorders. Nat Genet 17:445-448.

Rosewich H, Ohlenbusch A, Gartner J. 2005. Genetic and clinical aspects of Zellweger spectrum patients with PEX1 mutations. J Med Genet 42:e58.

Sacksteder KA, Jones JM, South ST, Li X, Liu Y, Gould SJ. 2000. PEX19 binds multiple peroxisomal membrane proteins, is predominantly cytoplasmic, and is required for peroxisome membrane synthesis. J Cell Biol 148:931-944.

Saidowsky J, Dodt G, Kirchberg K, Wegner A, Nastainczyk W, Kunau WH, Schliebs W. 2001. The di-aromatic pentapeptide repeats of the human peroxisome import receptor PEX5 are separate high affinity binding sites for the peroxisomal membrane protein PEX14. J Biol Chem 276:34524-34529.

Shimozawa N, Nagase T, Takemoto Y, Suzuki Y, Fujiki Y, Wanders RJ, Kondo N. 2002. A novel aberrant splicing mutation of the PEX16 gene in two patients with Zellweger syndrome. Biochem Biophys Res Commun 292:109-112.

Shimozawa N, Suzuki Y, Orii T, Moser A, Moser HW, Wanders RJ. 1993. Standardization of complementation grouping of peroxisome-deficient disorders and the second Zellweger patient with peroxisomal assembly factor-1 (PAF-1) defect. Am J Hum Genet 52:843-844. 
Shimozawa N, Suzuki Y, Tomatsu S, Nakamura H, Kono T, Takada H, Tsukamoto T, Fujiki Y, Orii T, Kondo N. 1998. A novel mutation, R125X in peroxisome assembly factor-1 responsible for Zellweger syndrome. Hum Mutat Suppl 1:S134-S136.

Shimozawa N, Suzuki Y, Zhang Z, Imamura A, Ghaedi K, Fujiki Y, Kondo N. 2000a. Identification of PEX3 as the gene mutated in a Zellweger syndrome patient lacking peroxisomal remnant structures. Hum Mol Genet 9:1995-1999.

Shimozawa N, Suzuki Y, Zhang Z, Imamura A, Toyama R, Mukai S, Fujiki Y, Tsukamoto T, Osumi T, Orii T, Wanders RJ, Kondo N. 1999a. Nonsense and temperature-sensitive mutations in PEX13 are the cause of complementation group $\mathrm{H}$ of peroxisome biogenesis disorders. Hum Mol Genet 8:1077-1083.

Shimozawa N, Tsukamoto T, Nagase T, Takemoto Y, Koyama N, Suzuki Y, Komori M, Osumi T, Jeannette G, Wanders RJ, Kondo N. 2004. Identification of a new complementation group of the peroxisome biogenesis disorders and PEX14 as the mutated gene. Hum Mutat 23:552-558.

Shimozawa N, Zhang Z, Imamura A, Suzuki Y, Fujiki Y, Tsukamoto T, Osumi T, Aubourg P, Wanders RJ, Kondo N. 2000b. Molecular mechanism of detectable catalasecontaining particles, peroxisomes, in fibroblasts from a PEX2-defective patient. Biochem Biophys Res Commun 268:31-35.

Shimozawa N, Zhang Z, Suzuki Y, Imamura A, Tsukamoto T, Osumi T, Fujiki Y, Orii T, Barth PG, Wanders RJ, Kondo N. 1999b. Functional heterogeneity of C-terminal peroxisome targeting signal 1 in PEX5-defective patients. Biochem Biophys Res Commun 262:504-508.

South ST, Gould SJ. 1999. Peroxisome synthesis in the absence of preexisting peroxisomes. J Cell Biol 144:255-266.

South ST, Sacksteder KA, Li X, Liu Y, Gould SJ. 2000. Inhibitors of COPI and COPII do not block PEX3-mediated peroxisome synthesis. J Cell Biol 149:1345-1360.

Steinberg S, Chen L, Wei L, Moser A, Moser H, Cutting G, Braverman N. 2004. The PEX Gene Screen: molecular diagnosis of peroxisome biogenesis disorders in the Zellweger syndrome spectrum. Mol Genet Metab 83:252-263.

Steinberg SJ, Dodt G, Raymond GV, Braverman NE, Moser AB, Moser HW. 2006. Peroxisome biogenesis disorders. Biochim Biophys Acta 1763:1733-1748.

Steinberg SJ, Snowden A, Braverman NE, Chen L, Watkins PA, Clayton PT, Setchell KD, Heubi JE, Raymond GV, Moser AB, Moser HW. 2009. A PEX10 defect in a patient with no detectable defect in peroxisome assembly or metabolism in cultured fibroblasts. J Inherit Metab Dis 32:109-119.

Tamura S, Matsumoto N, Imamura A, Shimozawa N, Suzuki Y, Kondo N, Fujiki Y. 2001. Phenotype-genotype relationships in peroxisome biogenesis disorders of PEX1defective complementation group 1 are defined by Pex1p-Pex6p interaction. Biochem J 357:417-426. 
Tamura S, Okumoto K, Toyama R, Shimozawa N, Tsukamoto T, Suzuki Y, Osumi T, Kondo N, Fujiki Y. 1998. Human PEX1 cloned by functional complementation on a CHO cell mutant is responsible for peroxisome-deficient Zellweger syndrome of complementation group I. Proc Natl Acad Sci U S A 95:4350-4355.

van Grunsven EG, van BE, Mooijer PA, Watkins PA, Moser HW, Suzuki Y, Jiang LL, Hashimoto T, Hoefler G, Adamski J, Wanders RJ. 1999. Peroxisomal bifunctional protein deficiency revisited: resolution of its true enzymatic and molecular basis. Am J Hum Genet 64:99-107.

Walter C, Gootjes J, Mooijer PA, Portsteffen H, Klein C, Waterham HR, Barth PG, Epplen JT, Kunau WH, Wanders RJ, Dodt G. 2001. Disorders of peroxisome biogenesis due to mutations in PEX1: phenotypes and PEX1 protein levels. Am J Hum Genet 69:3548.

Wanders RJ, Waterham HR. 2005. Peroxisomal disorders I: biochemistry and genetics of peroxisome biogenesis disorders. Clin Genet 67:107-133.

Wanders RJ, Waterham HR. 2006. Biochemistry of mammalian peroxisomes revisited. Annu Rev Biochem 75:295-332.

Warren DS, Morrell JC, Moser HW, Valle D, Gould SJ. 1998. Identification of PEX10, the gene defective in complementation group 7 of the peroxisome-biogenesis disorders. Am J Hum Genet 63:347-359.

Warren DS, Wolfe BD, Gould SJ. 2000. Phenotype-genotype relationships in PEX10deficient peroxisome biogenesis disorder patients. Hum Mutat 15:509-521.

Waterham HR, Koster J, van Roermund CW, Mooyer PA, Wanders RJ, Leonard JV. 2007. A lethal defect of mitochondrial and peroxisomal fission. N Engl J Med 356:1736-1741.

Weller S, Cajigas I, Morrell J, Obie C, Steel G, Gould SJ, Valle D. 2005. Alternative splicing suggests extended function of PEX26 in peroxisome biogenesis. Am J Hum Genet 76:987-1007.

Weller S, Gould SJ, Valle D. 2003. Peroxisome biogenesis disorders. Annu Rev Genomics Hum Genet 4:165-211.

Yik WY, Steinberg SJ, Moser AB, Moser HW, Hacia JG. 2009. Identification of novel mutations and sequence variation in the Zellweger syndrome spectrum of peroxisome biogenesis disorders. Hum Mutat 30:E467-E480.

Zeharia A, Ebberink MS, Wanders RJ, Waterham HR, Gutman A, Nissenkorn A, Korman SH. 2007. A novel PEX12 mutation identified as the cause of a peroxisomal biogenesis disorder with mild clinical phenotype, mild biochemical abnormalities in fibroblasts and a mosaic catalase immunofluorescence pattern, even at 40 degrees C. J Hum Genet 52:599-606. 
Figure legend

Figure 1. Complementation testing by PEG fusion and by $P E X$ cDNA transfection.

Principle of the PEG fusion method. (A), a tester cell line with a known PEX gene defect and a patient cell line are fused by PEG treatment resulting in multi-nucleated cells. Cells are examined by catalase immunofluorescence microscopy to determine complementation (B) or non complementation (C). Principle of the PEX cDNA transfection assay. The pcDNA3-PEX expression vectors are co-transfected separately but together with eGFP-SKL into patient cells (D). Cells are examined by direct fluorescent microscopy to determine complementation (E) or non complementation (F). 
A
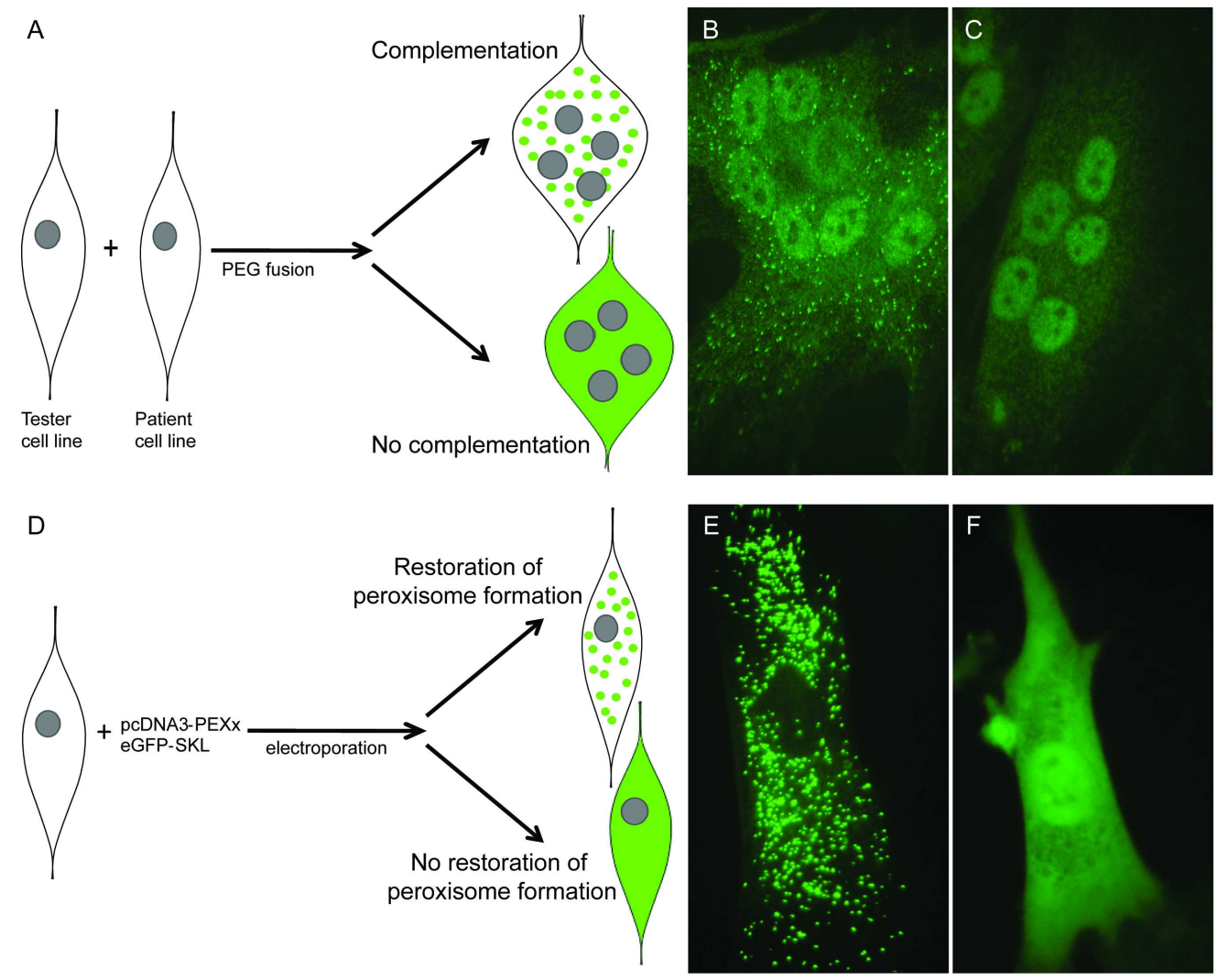

Complementation testing by PEG fusion and by PEX CDNA transfection. $228 \times 185 \mathrm{~mm}(300 \times 300 \mathrm{DPI})$ 
Table 1. Frequency distribution of PEX gene defects in ZSS.

Classification of the 613 different patient cell lines was done by either genetic

complementation (cDNA transfection of PEG fusion) or by sequence analysis.

\begin{tabular}{|c|c|c|c|c|c|c|}
\hline \multirow[t]{2}{*}{ PEX gene } & \multirow{2}{*}{$\begin{array}{c}\text { Genetic complementation } \\
\text { (Number of cell lines) }\end{array}$} & \multirow{2}{*}{$\begin{array}{l}\text { Frequency } \\
\qquad(\%)\end{array}$} & \multicolumn{4}{|c|}{ Number of cell lines sequenced and mutations } \\
\hline & & & Total & Homozygous 1 & 2x Heterozygous & 1x Heterozygous \\
\hline PEX1 & 358 & 58 & 180 & 74 & $68^{2}$ & $38^{\underline{3}}$ \\
\hline PEX2 & 23 & 4 & 22 & 17 & 2 & $3^{4,5}$ \\
\hline PEX3 & 3 & $<1$ & 3 & 3 & & \\
\hline PEX5 & 13 & 2 & 13 & 13 & & \\
\hline PEX6 & 97 & 16 & 77 & 45 & 32 & \\
\hline PEX10 & 19 & 3 & 18 & 10 & 7 & $1^{\underline{5}}$ \\
\hline PEX12 & 54 & 9 & 43 & 29 & 14 & \\
\hline PEX13 & 10 & 1 & 7 & 7 & & \\
\hline PEX14 & 3 & $<1$ & 2 & 1 & & $1^{\frac{5}{4}}$ \\
\hline PEX16 & 8 & 1 & 8 & 8 & & \\
\hline PEX19 & 4 & $<1$ & 3 & 3 & & \\
\hline PEX26 & 21 & 3 & 17 & 15 & 2 & \\
\hline Total & 613 & & 393 & & & \\
\hline
\end{tabular}

${ }^{1}$ These mutations appear homozygous, but a genomic deletion of one allele cannot be excluded.

${ }^{2}$ This number of cell lines includes 2 cell lines with 3 heterozygous mutations. ${ }^{3}$ Mutation analysis of the PEX1 gene by RFLP analysis identified the p.G843D mutation heterozygous in 38 patients; the $P E X 1$ gene in these patients was not further screened by sequence analysis.

$\frac{{ }^{4} \text { Only coding exon } 4 \text { was sequenced. }}{5}$.

${ }_{5}^{5}$ did not analyze the corresponding $\mathrm{CDNA}$ in these cell lines 
Table 2. Mutations in the $P E X 1$ gene.

\begin{tabular}{|c|c|c|c|c|c|c|}
\hline \multirow[b]{2}{*}{ Exon } & \multirow{2}{*}{$\begin{array}{l}\text { Mutations } \\
\text { Nucleotide }\end{array}$} & \multirow[b]{2}{*}{ Amino acid } & \multicolumn{2}{|c|}{$\begin{array}{l}\text { Number of patients } \\
\text { identified in this study }\end{array}$} & \multirow[b]{2}{*}{ Reference } & \\
\hline & & & Homozygous & Heterozygous & & \\
\hline 1 & c. $2 \mathrm{~T}>\mathrm{C}$ & unknown & 3 & & this study & Deleted: 1 \\
\hline 1 & c. $3 \mathrm{G}>\mathrm{A}$ & unknown & & 1 & this study & \\
\hline 1 & c. $5 \mathrm{G}>\mathrm{A}$ & p.W2X & & 1 & this study & \\
\hline 1 & c.56_57delTG & p.V19GfsX48 & & 1 & this study & \\
\hline 2 & c. $130-2 \mathrm{~A}>\mathrm{T}$ & $-\quad y_{0}$ & & 1 & this study & \\
\hline i2 & c. $273+1 G>A$ & - & & 1 & this study & \\
\hline$\underline{3}$ & c. $274 \mathrm{G}>\mathrm{C}$ & p.V92L & & & (Rosewich et al., 2005) & \\
\hline 3 & c.343_344insCT & p.D115AfsX18 & 1 & & this study & \\
\hline 4 & c.434_448delinsGCAA & p.V145_Q150delinsGfsX24 & & 1 & (Walter et al., 2001) & \\
\hline 5 & c. $547 \mathrm{C}>\mathrm{T}$ & p.R183X & & 1 & (Yik et al., 2009) & \\
\hline 5 & c. $569 \mathrm{C}>\mathrm{A}$ & p.S190X & & 4 & this study & Deleted: 6 \\
\hline 5 & c. $616 \mathrm{C}>\mathrm{T}$ & p.Q206X & & $\underline{1}$ & this study & Deleted: 2 \\
\hline 5 & c. $781 \mathrm{C}>\mathrm{T}$ & p.Q261X & & & (Tamura et al., 2001) & \\
\hline 5 & c.782-783delAA & p.Q261RfsX8 & 3 & & (Yik et al., 2009) & \\
\hline 5 & c.904delG & p.A302QfsX23 & & & (Maxwell et al., 2005; Maxwell et al., 2002) & \\
\hline 5 & c.911_912delCT & p.S304fsX3 & & 1 & (Rosewich et al., 2005) & Deleted: this study \\
\hline 5 & c. $1007 \mathrm{~T}>\mathrm{C}$ & p.V336A ${ }^{1}$ & & 1 & this study & \\
\hline 5 & c.1108_1109insA & p.I370NfsX2 & 1 & & (Maxwell et al., 2005) & \\
\hline 5 & c.1193delT & p.I398TfsX7 & & 1 & this study & \\
\hline i5 & c. $1239+1 \mathrm{G}>\mathrm{T}$ & - & & 1 & (Yik et al., 2009) & \\
\hline 6 & c. $1340 \mathrm{~T}>\mathrm{C}$ & p.L447S & & 1 & this study & \\
\hline 7 & c.1370insT & p.S458KfsX2 & & 1 & this study & \\
\hline 7 & c. $1411 \mathrm{C}>\mathrm{T}$ & p.Q471X & & 1 & this study & \\
\hline
\end{tabular}




\begin{tabular}{|c|c|c|c|c|c|c|c|}
\hline 7 & c. $1414 \mathrm{C}>\mathrm{T}$ & p.Q472X & & 1 & this study & & \\
\hline 8 & c.1501_1502delCT & p.L501X & & 1 & this study & & \\
\hline 8 & c.1509_1510dupTA & p.V504X & & 1 & this study & & \\
\hline 8 & c. $1579 A>G$ & p.T526A $\mathrm{A}^{\frac{1}{2}}$ & & 1 & this study & & \\
\hline 9 & c. $1663 \mathrm{~T}>\mathrm{C}$ & p.S555P & & 1 & this study & & \\
\hline i9 & c. $1670+5 \mathrm{G}>\mathrm{T}$ & - & 1 & & (Walter et al., 2001) & & \\
\hline 10 & c. $1706 \mathrm{~A}>\mathrm{C}$ & p.H569P & 1 & & this study & & \\
\hline 10 & c.1713_1716delTCAC & p.H571fsX10 & & 1 & this study & & \\
\hline 10 & c.1716_1717delCA & p.H572QfsX19 & & 2 & (Yik et al., 2009) & & \\
\hline 10 & c. $1777 \mathrm{G}>\mathrm{A}$ & p.G593R & & 1 & (Walter et al., 2001) & & \\
\hline 11 & c.1842delA & p.E615KfsX30 & & 1 & this study & & \\
\hline 11 & c.1865_1866insCAGTGTGGA & - & & & (Preuss et al., 2002) & & \\
\hline 11 & c.1886_1887delGT & p.C629X & & 1 & this study & & \\
\hline 11 & c.1891delG & p.A631LfsX14 & & 1 & this study & & \\
\hline 11 & c. $1897 \mathrm{C}>\mathrm{T}$ & p.R633X & & & (Tamura et al., 2001) & & \\
\hline 12 & r.1900_2070del & p.G634_H690del & & & (Tamura et al., 1998) & & \\
\hline 12 & c. $1957 \mathrm{~T}>\mathrm{A}$ & p.W653R & & 1 & this study & & \\
\hline 12 & c.1960_1961dupCAGTGTGGA & p.T651_W653dup & & 1 & $\begin{array}{l}\text { (Gartner et al., 1999; Portsteffen et al., 1997; } \\
\text { Preuss et al., 2002; Reuber et al., 1997) }\end{array}$ & & \\
\hline 12 & c.1976T>A & p.V659D & & 1 & this study & & \\
\hline 12 & c.1991T>C & p.L664P & & & (Tamura et al., 2001) & & \\
\hline 12 & c. $2008 \mathrm{C}>\mathrm{A}$ & p.L670M & & 1 & (Walter et al., 2001) & & \\
\hline 12 & c.2034_2035delCA & p.H678QfsX15 & & 1 & (Steinberg et al., 2004) & & \\
\hline 12 & c. $2071+1 \mathrm{G}>\mathrm{T}$ & - & & 5 & (Walter et al., 2001) & & \\
\hline$\underline{13}$ & c.2083_2085delATG & p.M695del & & & (Rosewich et al., 2005) & & \\
\hline 13 & c.2085-2089delGATAA & p.M695IfsX45 & & & (Steinberg et al., 2004) & Deleted: 13 &. .1 \\
\hline \multirow[t]{2}{*}{13} & \multirow{2}{*}{ c.2097_2098insT } & \multirow{2}{*}{ p.I700fsX41 } & \multirow{2}{*}{$1 \underline{6}$} & \multirow[t]{2}{*}{32} & \multirow{2}{*}{$\begin{array}{l}\text { (Collins and Gould, } 1999 \text {; Maxwell et al., } 2005 \text {; } \\
\text { Preuss et al.,2002; Steinberg et al., 2004; Walter- }\end{array}$} & Deleted: 5 & \\
\hline & & & & & & Deleted: 3 & \\
\hline
\end{tabular}




\begin{tabular}{|c|c|c|c|c|c|c|}
\hline 13 & c. $2224 \mathrm{C}>\mathrm{T}$ & p.Q742X & & 2 & this study & \\
\hline 13 & c.2227_2416del & p.E743NfsX2fs & & & (Preuss et al., 2002) & \\
\hline 14 & c. $2364 \mathrm{G}>\mathrm{A}$ & Deletion exon 14 & & 1 & this study & Deleted: p.V788V \\
\hline 14 & c. $2368 \mathrm{C}>\mathrm{T}$ & p.R790X & & 1 & (Maxwell et al., 2002) & Deleted: 2 \\
\hline 14 & c. $2383 \mathrm{C}>\mathrm{T}$ & p.R795X & & 1 & (Collins and Gould, 1999) & \\
\hline 14 & c. $2387 \mathrm{~T}>\mathrm{C}$ & p.L796P & & 1 & (Rosewich et al., 2005) & \\
\hline 14 & c.2391_2392delTC & p.R798SfsX35 & & & (Maxwell et al., 2005) & \\
\hline 14 & c. $2392 \mathrm{C}>\mathrm{G}$ & p.R798G & & 1 & (Maxwell et al., 2002) & \\
\hline 15 & c. $2528 \mathrm{G}>\mathrm{A}$ & p.G843D & 42 & 62 & $\begin{array}{l}\text { (Collins and Gould, 1999; Maxwell et al., 2002; } \\
\text { Preuss et al.., 2002; Steinberg et al., 2004; Walter }\end{array}$ & Deleted: 4 \\
\hline 15 & c.2537_2545delATGAAGTTAinsTCATGGT & p.H846_R849delinsLfsX53 & & & $\begin{array}{l}\text { et al., 2001) } \\
\text { (Steinberg et al., 2004) }\end{array}$ & Deleted: 9 \\
\hline 15 & 14bpinsex 15 & - & & & (Reuber et al., 1997) & \\
\hline 16 & c. $2614 \mathrm{C}>\mathrm{T}$ & p.R872X & 2 & 1 & (Preuss et al., 2002) & Deleted: 1 \\
\hline 16 & c.2633_2635 delTGT & p.L879del & 1 & 1 & this study & \\
\hline 16 & c. $2636 \mathrm{~T}>\mathrm{C}$ & p.L879S & & 3 & this study & Deleted: 2 \\
\hline$\underline{16}$ & c. $2654 \mathrm{C}>\mathrm{G}$ & p.T885R & & 1 & this study & \\
\hline 17 & c.2730delA & p.1910fsX50 & 1 & 4 & (Walter et al., 2001) & \\
\hline 17 & c.2760delA & p.A921LfsX40 & 1 & & this study & \\
\hline 18 & c.2814_2818delCTTTG & p.F938LfsX2 & & & (Preuss et al., 2002) & \\
\hline 18 & c. $2845 \mathrm{C}>\mathrm{T}$ & p.R949W & & 1 & this study & \\
\hline 18 & c. $2846 \mathrm{G}>\mathrm{A}$ & p.R949Q & & 2 & (Walter et al., 2001) & \\
\hline 18 & c.2916delA & p.G973AfsX16 & 1 & 4 & $\begin{array}{l}\text { (Maxwell et al., 2002; Preuss et al., 2002; } \\
\text { Steinberg et al., 2004) }\end{array}$ & \\
\hline 18 & c. $2926+1 \mathrm{G}>\mathrm{A}$ & - & & 1 & (Steinberg et al., 2004) & \\
\hline 18 & c. $2926+2 \_2926+3$ insT & - & & & (Collins and Gould, 1999) & \\
\hline 18 & c. $2926+2 T>C$ & - & & & (Walter et al., 2001) & \\
\hline
\end{tabular}


c. $2927-15$ T 3208 -

\begin{tabular}{|c|c|c|c|}
\hline $\begin{array}{l}\text { 342AdelinsATAGTATAGA \& } \\
\text { c.3849+779_3849+2910 }\end{array}$ & del ex19/20 & 2 & this study \\
\hline c. $2966 \mathrm{~T}>\mathrm{C}$ & p.I989T & & (Maxwell et al., 2005) \\
\hline c. $2992 \mathrm{C}>\mathrm{T}$ & p.R998X & & (Maxwell et al., 2002) \\
\hline c. $2993 \mathrm{G}>\mathrm{A}$ & p.R998Q & & (Maxwell et al., 2005) \\
\hline c.3022_3024delCCT & p.P1008del & & (Steinberg et al., 2004) \\
\hline c. $3038 \mathrm{G}>\mathrm{A}$ & p.R1013H & & (Rosewich et al., 2005) \\
\hline c.3180_3181insT & p.G1061WfsX16 & & (Collins and Gould, 1999) \\
\hline c. $3207+1 \mathrm{G}>\mathrm{C}$ & - & & (Collins and Gould, 1999) \\
\hline c. $3287 \mathrm{C}>\mathrm{G}$ & p.S1096X & & (Rosewich et al., 2005) \\
\hline c. $3378 \mathrm{C}>\mathrm{G}$ & p.Y1126X & & (Preuss et al., 2002) \\
\hline c.3692-3695delAGTC & p.Q1231HfsX3 & 1 & (Yik et al., 2009; Rosewich et al., 2005) \\
\hline c. $3850 \mathrm{~T}>\mathrm{C}$ & p.X1284QnextX29 & 1 & (Walter et al., 2001) \\
\hline
\end{tabular}

24 c. $3850 \mathrm{~T}>\mathrm{C}$

(Walter et al., 2001)

Reference sequence of PEXI: GenBank accession number NM_000466.2. Nucleotide numbering starting at the first adenine of the translation initiation codon ATG.

Possibly this mutation is a rare sequence variation, for details see text. 


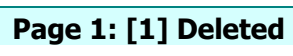

13 c. $2088 \mathrm{~A}>\mathrm{G}$

\section{Merel}

7/5/2010 5:42:00 PM

10

11

12

13

14

15

16

17

18

19

20

21

22

23

24

25

26

27

28

29

30

31

32

33

34

35

36

37

38

39

40

41

42

43

44

45

46

47

48

49

50

51

52

53

54

55

56

57

58

59

60

John Wiley \& Sons, Inc. 
Table 3. Mutations in the PEX2 gene.

\begin{tabular}{|c|c|c|c|c|c|c|}
\hline \multirow[b]{2}{*}{ Exon } & \multicolumn{2}{|c|}{ Mutations } & \multicolumn{2}{|c|}{ Number of patients identified in this study } & \multirow[b]{2}{*}{ Reference } & \\
\hline & Nucleotide & Amino acid & Homozygous & Heterozygous & & \\
\hline 4 & c. $115 \mathrm{C}>\mathrm{T}$ & p.Q39X & & & (Krause et al., 2006) & \\
\hline 4 & c. $163 \mathrm{G}>\mathrm{A}$ & p.E55K & & & (Imamura et al., 1998b; Steinberg et al., 2004) & $\ldots[1]$ \\
\hline 4 & c.273delT & p.N92TfsX2 & & & (Steinberg et al., 2004) & \\
\hline 4 & c.279_283delGAGAT & p.R94SfsX5 & 2 & 1 & (Gootjes et al., 2004a) & Deleted: 1 \\
\hline 4 & c. $286 \mathrm{C}>\mathrm{T}$ & p.Q96X & 1 & & this study & \\
\hline 4 & c.325insT & p.C109LfsX14 & & 1 & this study & \\
\hline 4 & c.339_345delCAGGTGG & p.R114X & 1 & 1 & this study & \\
\hline 4 & c. $355 \mathrm{C}>\mathrm{T}$ & p.R119X & 4 & 1 & $\begin{array}{l}\text { (Imamura et al., 1998b; Shimozawa et al., 1993; } \\
\text {-Steinberg et-at., 2004)- }\end{array}$ & Deleted: 2 \\
\hline 4 & c. $373 \mathrm{C}>\mathrm{T}$ & p.R125X & & & $\begin{array}{l}\text { (Imamura et al., 1998b; Shimozawa et al., 1998; } \\
\text { Steinberg et al., 2004) }\end{array}$ & \\
\hline 4 & c.550delC & p.R184VfsX8 & 3 & & (Shimozawa et al., 2000b) & \\
\hline 4 & c.642delG & p.K215SfsX2 & 1 & & (Shimozawa et al., 2000b) & \\
\hline 4 & c. $669 \mathrm{G}>\mathrm{A}$ & p.W223X & 2 & & (Gootjes et al., 2004a) & \\
\hline 4 & c.739T $>\mathrm{C}$ & p.C247R & 1 & & (Gootjes et al., 2004a) & \\
\hline 4 & c. $782 \mathrm{~A}>\mathrm{G}$ & p.H261R & & 1 & this study & Deleted: 2 \\
\hline 4 & c. $791 \mathrm{G}>\mathrm{A}$ & p.C264Y & 1 & & this study & \\
\hline 4 & c.834_838delTACTT & p.F278LfsX3 & & 1 & (Krause et al., 2006) & \\
\hline 4 & c.866insA & p.S289fsX36 & . & 1 & this study & Deleted: 4 \\
\hline
\end{tabular}


1

2

3

4

5

6

7

8

9

10

11

12

13

14

15

16

17

18

19

20

21

22

23

24

25

26

27

28

29

30

31

32

33

34

35

36

37

38

39

40

41

42

43

44

45

46

47

48

49

50

51

52

53

54

55

56

57

58

59

60
Page 1: [1] Deleted $-58 \mathrm{G}>\mathrm{T}$

\section{7/5/2010 7:03:00 PM}

(Steinberg et al., 20

John Wiley \& Sons, Inc. 
Table 4. Mutations in the PEX3 gene.

\begin{tabular}{|c|c|c|c|c|c|}
\hline \multirow[b]{2}{*}{ Exon } & \multicolumn{2}{|c|}{ Mutations } & \multicolumn{2}{|c|}{ Number of patients identified in this study } & \multirow[b]{2}{*}{ Reference } \\
\hline & Nucleotide & Amino acid & Homozygous & Heterozygous & \\
\hline 2 & c. $157 \mathrm{C}>\mathrm{T}$ & p.R53X & & & (South et al., 2000) \\
\hline 4 & c.328_331delATAA & p.I110VfsX23 & 1 & & this study \\
\hline 5 & r.334_393del & p.F112_V131del & 1 & & this study \\
\hline 7 & c.543_544insT & p.V182CfsX2 & & & (Muntau et al., 2000; Shimozawa et al., 2000a; South et al., 2000) \\
\hline 10 & c. $856 \mathrm{c}>\mathrm{t}$ & p.R286X & 1 & & (Dursun et al., 2009) \\
\hline 11 & c. $942-8 \mathrm{~T}>\mathrm{G}$ & p.S314RfsX3 & & & (Ghaedi et al., 2000; Muntau et al., 2000) \\
\hline
\end{tabular}


Table 5. Mutations in the PEX5 gene.

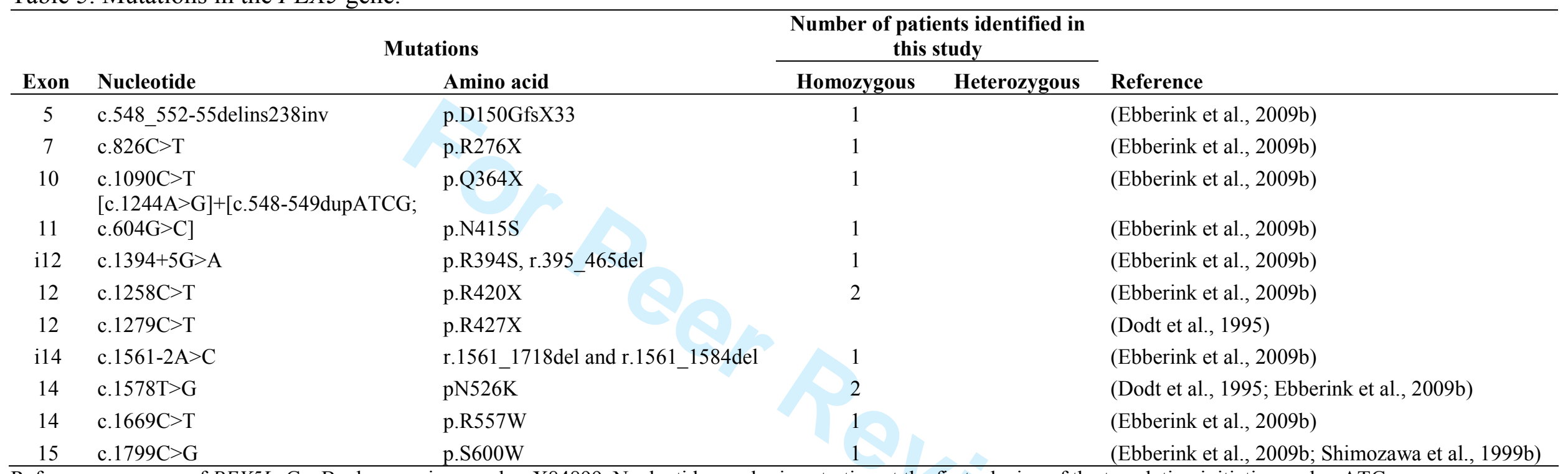

Reference sequence of PEX5L: GenBank accession number X84899. Nucleotide numbering starting at the first adenine of the translation initiation codon ATG. 
Table 6. Mutations in the PEX10 gene.

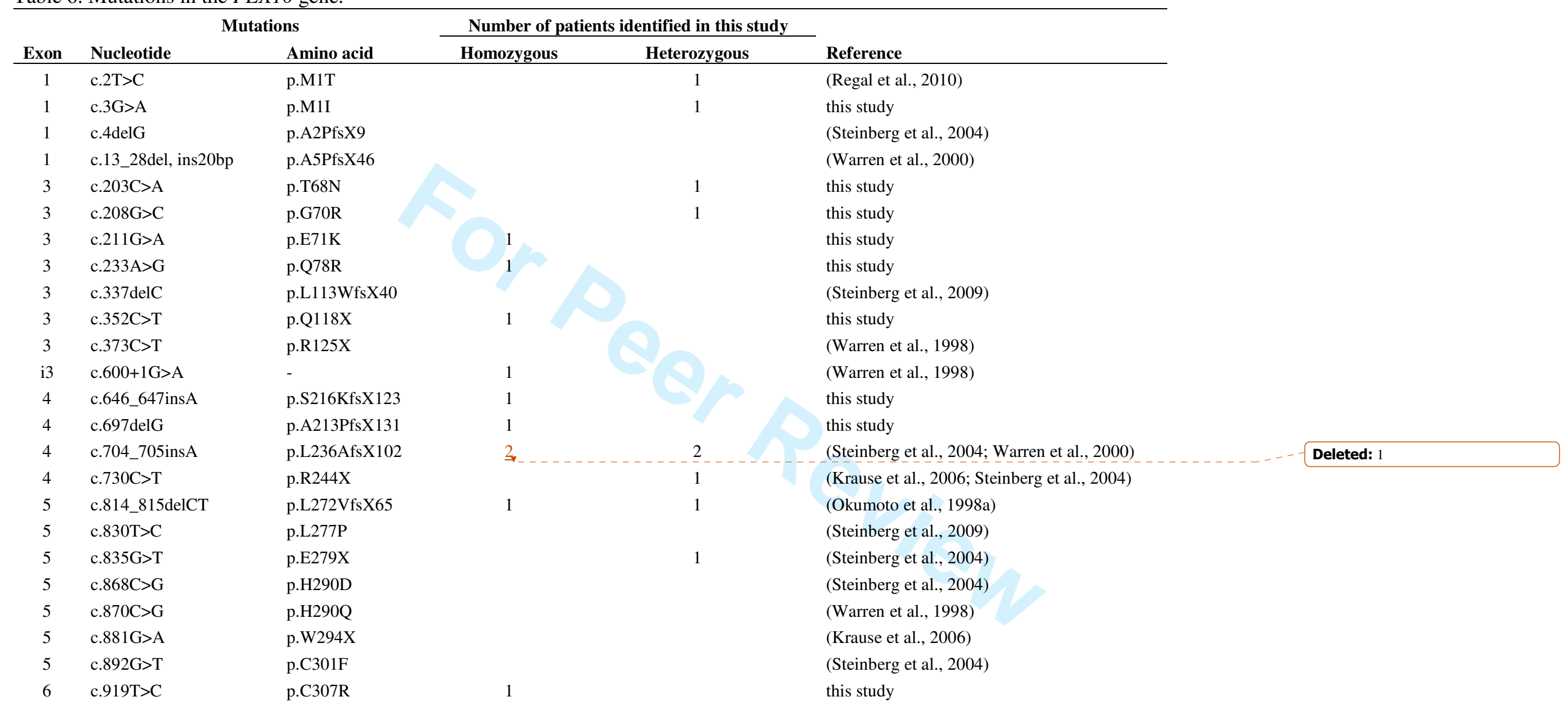


$\begin{array}{lllll}6 & \text { c.932G }>\mathrm{A} & \text { p.R311Q } & 1 & \text { (Regal et al., 2010) }\end{array}$ Reference sequence of PEX10: GenBank accession number NM_002617.3. Nucleotide numbering starting at the first adenine of the translation initiation codon ATG. 
Table 7. Mutations in the PEX12 gene.

\begin{tabular}{|c|c|c|c|c|c|c|}
\hline \multirow[b]{2}{*}{ Exon } & \multirow[b]{2}{*}{ Nucleotide } & \multirow[b]{2}{*}{ Amino acid } & \multicolumn{2}{|c|}{$\begin{array}{l}\text { Number of patients identified in } \\
\text { this study }\end{array}$} & \multirow[b]{2}{*}{ Reference } & \\
\hline & & & Homozygous & Heterozygous & & \\
\hline 1 & c.16dupG & p.A6GfsX11 & & 1 & this study & \\
\hline 1 & c.26_27delCA & p.T9SfsX7 & & & (Chang and Gould, 1998) & \\
\hline 1 & c. $102 \mathrm{~A}>\mathrm{T}$ & p.R34S & 1 & & (Zeharia et al., 2007) & \\
\hline 1 & c. $126+1 \mathrm{G}>\mathrm{T}$ & - & 3 & 5 & (Chang and Gould, 1998) & Deleted: 2 \\
\hline 2 & c.202_204delCTT & p.L68del & & & (Chang and Gould, 1998) & \\
\hline 2 & c. $220 \mathrm{~T}>\mathrm{G}$ & p.Y74D & & 1 & this study & \\
\hline 2 & c.260_261insAA & p.Y87X & & & (Steinberg et al., 2004) & \\
\hline 2 & c.268_271delAAGA & p.K90EfsX3 & & & (Chang and Gould, 1998) & \\
\hline 2 & c. $273 \mathrm{~A}>\mathrm{T}$ & p.R91S & 1 & & (Gootjes et al., 2004c) & Deleted: 2 \\
\hline 2 & c.308_309insT & p.L103FfsX3 & 1 & & (Gootjes et al., 2004c) & \\
\hline 2 & c.378_380delTTC & p.L126del & & 1 & this study & \\
\hline 2 & c.445_454delTCTTCCCGCT & p.S149GfsX15 & & 1 & this study & \\
\hline 2 & c. $460 \mathrm{C}>\mathrm{T}$ & p.R154X & & 1 & this study & \\
\hline 2 & c.478_479delCA & p.Y156X & & 1 & this study & \\
\hline 2 & c.531_533delACA & p.Q178del & & & (Yik et al., 2009) & \\
\hline 2 & c.533_535delAAC & p.Q178del & 1 & 1 & (Steinberg et al., 2004) & \\
\hline 2 & c. $538 \mathrm{C}>\mathrm{T}$ & p.R180X & & 2 & (Chang et al., 1999; Okumoto et al., 1998b) & \\
\hline 2 & c.541_542insT & p.Y181LfsX37 & & & (Steinberg et al., 2004) & \\
\hline 2 & c. $604 \mathrm{C}>\mathrm{T}$ & p.R202X & 3 & & (Gootjes et al., 2004c) & \\
\hline 2 & c. $625 \mathrm{C}>\mathrm{T}$ & p.Q209X & & 2 & (Gootjes et al., 2004c) & \\
\hline i2 & c. $681-2 \mathrm{~A}>\mathrm{C}$ & - & & & (Steinberg et al., 2004) & \\
\hline 3 & c.684_687delTAGT & p.S222RfsX3 & & & (Chang and Gould, 1998) & \\
\hline 3 & c. $691 \mathrm{~A}>\mathrm{T}$ & p.K231X & & & (Okumoto and Fujiki, 1997) & \\
\hline 3 & c.733_734dupGCCT & p.L245CfsX19 & & 1 & (Chang et al., 1999; Steinberg et al., 2004) & \\
\hline
\end{tabular}




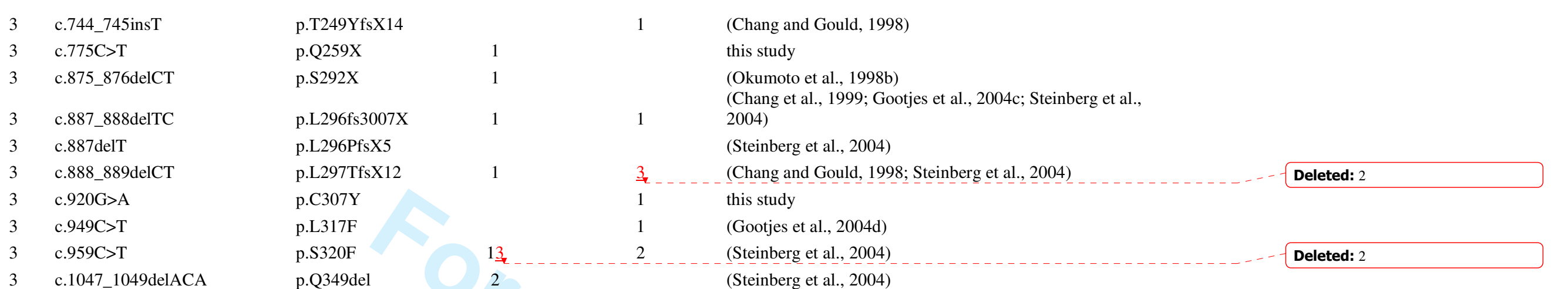
$\frac{3}{\text { Reference sequence of PEX12: GenBank accession number NM_000286.2. Nucleotide numbering starting at the first adenine of the translation initiation codon ATG. }}$ 


\section{Page 39 of 48}

Human Mutation

Table 8. Mutations in the PEX13 gene.

\begin{tabular}{|c|c|c|c|c|c|}
\hline \multirow[b]{2}{*}{ Exon } & \multicolumn{2}{|c|}{ Mutations } & \multicolumn{2}{|c|}{ Number of patients identified in this study } & \multirow[b]{2}{*}{ Reference } \\
\hline & Nucleotide & Amino acid & Homozygous & Heterozygous & \\
\hline i1 & c. $92+2 \mathrm{~T}>\mathrm{G}$ & - & 1 & & this study \\
\hline 2 & c.107_120del & p.G36DfsX61 & & & (Al-Dirbashi et al., 2009) \\
\hline 2 & c.439_441delATG & p.M147del & 1 & & this study \\
\hline 2 & c. $676 \mathrm{C}>\mathrm{T}$ & p.R226X & 2 & & this study \\
\hline 2 & c. $702 \mathrm{G}>\mathrm{A}$ & p.W234X & 1 & & (Shimozawa et al., 1999a) \\
\hline 4 & c.937T >G & p.W313G & & & (Krause et al., 2006) \\
\hline 4 & c. $970 \mathrm{G}>\mathrm{T}$ & p.G324X & & & (Shimozawa et al., 1999a) \\
\hline 4 & c. $977 \mathrm{~T}>\mathrm{C}$ & p.I326T & 1 & & (Liu et al., 1999; Shimozawa et al., 1999a) \\
\hline 4 & c. $980 \mathrm{c}>\mathrm{g}$ & p.P327R & 1 & & this study \\
\hline $1-4$ & c. $1 \_1212^{1}$ & - & & & (Al-Dirbashi et al., 2009) \\
\hline
\end{tabular}

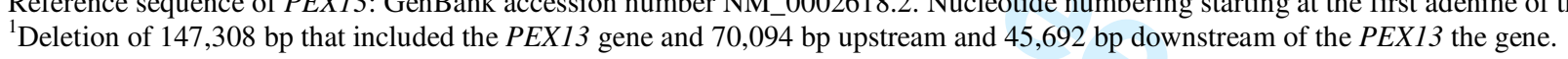


Table 9. Mutations in the PEX14 gene.

\begin{tabular}{|c|c|c|c|c|c|}
\hline \multirow[b]{2}{*}{ Exon } & \multirow[b]{2}{*}{ Nucleotide } & \multirow{2}{*}{$\begin{array}{l}\text { Mutations } \\
\text { Amino acid }\end{array}$} & \multicolumn{2}{|c|}{ Number of patients identified in this study } & \multirow[b]{2}{*}{ Reference } \\
\hline & & & Homozygous & Heterozygous & \\
\hline 3 & c.85-?_170+?del & p.[Ile29_Lys56del;Gly57GlyfsX2] & $\underline{1}$ & & (Huybrechts et al., 2008) \\
\hline 7 & c. $.553 \mathrm{C}>\mathrm{T}$ & p.Gln185Ter & & & (Shimozawa et al., 2004) \\
\hline 7 & c. $585+1 \mathrm{G}>\mathrm{T}$ & r.585+1_37ins & & $\underline{1}$ & this study \\
\hline
\end{tabular}


Table 10. Mutations in the PEX16 gene.

\begin{tabular}{lllccl} 
& \multicolumn{2}{c}{ Mutations } & \multicolumn{2}{c}{ Number of patients identified in this study } & \\
\cline { 3 - 4 } Exon & \multicolumn{1}{c}{ Nucleotide } & Amino acid & Homozygous & Heterozygous & Reference \\
\hline i5 & c. $460+2$ insG & - & 1 & this study \\
6 & c.526C $>$ T & p.R176X & & (Honsho et al., 1998; South and Gould, 1999) \\
8 & c. $753 \_755$ delTGT & p.V252del & 1 & Ebberink 2010 \\
9 & c.865C $>$ A & p.P289T & 1 & Ebberink 2010 \\
i11 & c.952+118_1011+80 & & 1 & Ebberink 2010 \\
i10 & c.952+2T $>$ C & R298fsX38 & 2 & (Shimozawa et al., 2002) \\
11 & c. 984 delG & p.I330SfsX27 & 1 & Ebberink 2010 \\
11 & c.992A $>$ G & p.Y331C & 1 & Ebberink 2010 \\
\hline
\end{tabular}

Reference sequence of PEX16: GenBank accession number NM_0004813.2. Nucleotide numbering starting at the first adenine of the translation initiation codon ATG. 
Table 11. Mutations in the PEX19 gene.

\begin{tabular}{|c|c|c|c|c|c|c|}
\hline \multirow[b]{2}{*}{ Exon } & \multicolumn{2}{|c|}{ Mutations } & \multicolumn{2}{|c|}{ Number of patients identified in this study } & \multirow[b]{2}{*}{ Reference } & \\
\hline & Nucleotide & Amino acid & Homozygous & Heterozygous & & \\
\hline 3 & c.320delA & p.K320fsX13 & 1 & & this study & \\
\hline 6 & c. $739 \mathrm{c}>\mathrm{t}$ & p.Q257X & 1 & & this study & \\
\hline 6 & c.763_764insA & p.M255NfsX24 & $\underline{1}$ & . & (Matsuzono et al., 1999) & Deleted: 2 \\
\hline
\end{tabular}


Table 12. Mutations in the PEX26 gene.

\begin{tabular}{|c|c|c|c|c|c|}
\hline \multirow[b]{2}{*}{ Exon } & \multicolumn{2}{|c|}{ Mutations } & \multicolumn{2}{|c|}{$\begin{array}{c}\text { Number of patients identified in } \\
\text { this study }\end{array}$} & \multirow[b]{2}{*}{ Reference } \\
\hline & Nucleotide & Amino acid & Homozygous & Heterozygous & \\
\hline 2 & c. $2 \mathrm{~T}>\mathrm{C}$ & p.M1T & & & (Matsumoto et al., 2003b; Weller et al., 2005) \\
\hline 2 & c.34_35insC & p.L12PfsX103 & 2 & & (Matsumoto et al., 2003b) \\
\hline 2 & c.37_38delAG & p.R13GfsX164 & & & (Steinberg et al., 2004) \\
\hline 2 & c.73_79delGTGCGCG & p.V25RfsX55 & 1 & & this study \\
\hline 2 & c. $131 \mathrm{~T}>\mathrm{C}$ & p.L44P & & 1 & (Weller et al., 2005) \\
\hline 2 & c. $134 \mathrm{~T}>\mathrm{C}$ & p.L45P & & & (Matsumoto et al., 2003b; Weller et al., 2005) \\
\hline 2 & c. $185 \mathrm{G}>\mathrm{A}$ & p.W62X & 1 & & this study \\
\hline 2 & c.192_216del & p.S64RfsX10 & & & (Steinberg et al., 2004) \\
\hline $\mathrm{i} 2$ & c. $230+1 \mathrm{G}>\mathrm{T}$ & p.T77fsX139 & & & (Weller et al., 2005) \\
\hline 3 & c. $254 \_255$ insT & p.L85LfsX93 & & & (Matsumoto et al., 2003b; Weller et al., 2005) \\
\hline 3 & c. $265 \mathrm{G}>\mathrm{A}$ & p.G89R & & & (Matsumoto et al., 2003b) \\
\hline 3 & c. $292 \mathrm{C}>\mathrm{T}$ & p.R98W & $\underline{10}$ & 2 & (Matsumoto et al., 2003b; Steinberg et al., 2004; Weller et al., 2005) \\
\hline 3 & c. $296 \mathrm{G}>\mathrm{A}$ & p.W99X & & & (Steinberg et al., 2004) \\
\hline 3 & c. $315 \mathrm{~g}>\mathrm{a}$ & p.W105X & 1 & & this study \\
\hline 3 & c. $350 \mathrm{C}>\mathrm{T}$ & p.P117L & & & (Weller et al., 2005) \\
\hline 3 & c. $353 \mathrm{C}>\mathrm{G}$ & p.P118R & & & (Steinberg et al., 2004) \\
\hline i3 & c. $371+2 \mathrm{~T}>\mathrm{C}$ & - & & & (Steinberg et al., 2004) \\
\hline 4 & c.426_548dup122bpinsT & p.A143_V182dup+G183V & & & (Weller et al., 2005) \\
\hline 4 & c. $574 \mathrm{C}>\mathrm{T}$ & p.R192X & & 1 & (Steinberg et al., 2004) \\
\hline i4 & c. $667+2 \mathrm{~T}>\mathrm{C}$ & - & & & (Steinberg et al., 2004) \\
\hline 5 & r.668_814 & p.G223_P271del & & & (Matsumoto et al., 2003b) \\
\hline 6 & c.862delC & p.R288AfsX366 & & & (Weller et al., 2005) \\
\hline
\end{tabular}

Reference sequence of PEX26: GenBank accession number NM_017929.4. Nucleotide numbering starting at the first adenine of the translation initiation codon ATG. 
Supplemental Table S1. Primer sets used for PEX1 mutation analysis.

\begin{tabular}{|c|c|c|c|}
\hline Amplicon & Sequence $\left(5^{\prime} \rightarrow 3^{\prime}\right)^{1}$ & Exons & Regions of cDNA \\
\hline A & $\begin{array}{l}\text { [-21M13]-ACTACAGGCTTACGGCAG } \\
\text { [M13-Rev]-GACCTGGGATAAGACGAGC }\end{array}$ & 1 & \\
\hline$B$ & $\begin{array}{l}\text { [-21M13]-CAGCATTGGGTGTTGGAAATG } \\
\text { [M13-Rev]-ATTAGGTGACATCTCACCTCC }\end{array}$ & 2 & \\
\hline C & $\begin{array}{l}\text { [-21M13]-CCATCCAAAACATACACACAC } \\
\text { [M13-Rev]-AAGCTAAAGACATTGATATTGTG }\end{array}$ & 3 & \\
\hline D & $\begin{array}{l}\text { [-21M13]-TTAACTAGATATGGAGTGGAC } \\
\text { TACTTTGGACTCAATGCTATAG }\end{array}$ & 4 & \\
\hline$E$ & $\begin{array}{l}\text { [-21M13]-TATAGCATTGAGTCCAAAGTAG } \\
\text { [M13-Rev]-CTGGTCCCATGGAAATACATG }\end{array}$ & $5 \mathrm{~A}$ & \\
\hline$F$ & $\begin{array}{l}\text { [-21M13]-CAGAGTATGCAAATCTCAACC } \\
\text { [M13-Rev]-ATTTGGGGATGTTTAAGCCAC }\end{array}$ & $5 B$ & \\
\hline$G$ & $\begin{array}{l}\text { [-21M13]-ATGGACTGAGACAACTATGAG } \\
\text { [M13-Rev]-CTAAAGCAACTAGAAATCTTAC }\end{array}$ & 6 & \\
\hline $\mathrm{H}$ & $\begin{array}{l}\text { [-21M13]-GATTTGTTTGGTCAGGCTTAC } \\
\text { [M13-Rev]-CAGGTATGACAGGTTGCAAG }\end{array}$ & 7 & \\
\hline I & $\begin{array}{l}\text { [-21M13]-CTGTTTCAGTACTAACTCTGC } \\
\text { [M13-Rev]-CTTCACAATGCAAGGTGTTAC }\end{array}$ & 8 & \\
\hline J & $\begin{array}{l}\text { [-21M13]-CCCTGGATGGGTACATTGTT } \\
\text { [M13-Rev]-CTAGGCGTGAAGATAGAGAC }\end{array}$ & 9 & \\
\hline $\mathrm{K}$ & $\begin{array}{l}\text { [-21M13]-TATCCTGCTTCAGTCTTTTATC } \\
\text { [M13-Rev]-TTTCCATATGTCGTATAAACCC }\end{array}$ & 10 & \\
\hline L & $\begin{array}{l}\text { [-21M13]-GTGGTTGCCACAATGACAGG } \\
\text { [M13-Rev]-AGATTGACAGCATTATGTATAAC }\end{array}$ & 11 & \\
\hline M & $\begin{array}{l}\text { [-21M13]-CCTGAATTTTCCCAGCACTG } \\
\text { [M13-Rev]-GACTAACCATGAAGTTGCAGA }\end{array}$ & 12 & \\
\hline$N$ & $\begin{array}{l}\text { [-21M13]-CCTCACTAGACATTGCTCTG } \\
\text { [M13-Rev]-CCTCTAGCACAATATGCACC }\end{array}$ & 13 & \\
\hline $\mathrm{O}$ & $\begin{array}{l}\text { [-21M13]-GCCCTTTTACTACCCATTCC } \\
\text { [M13-Rev]-TACAGTGGTTCTTCTGGGAG }\end{array}$ & $14+15$ & \\
\hline$P$ & $\begin{array}{l}\text { [-21M13]-TTTTCTACTGTTGTACTTGCTG } \\
\text { [M13-Rev]-TGAATGCACTAAATGCCAGTG }\end{array}$ & 16 & \\
\hline Q & $\begin{array}{l}\text { [-21M13]-GGCAGAAGCATCAAGCATAG } \\
\text { [M13-Rev]-AGAGAATCCACGTCCTCTAG }\end{array}$ & 17 & \\
\hline$R$ & $\begin{array}{l}\text { [-21M13]-GCCAACTATGAAGCCTGA TTC } \\
\text { [M13-Rev]-CTGGCAGAAGTAAAGCTCAC }\end{array}$ & $18+19$ & \\
\hline S & $\begin{array}{l}\text { [-21M13]-GCTGTTGGTACATTTCTCAAC } \\
\text { [M13-Rev]-TCCAACTATGGAACATTCAACT }\end{array}$ & 20 & \\
\hline $\mathrm{T}$ & $\begin{array}{l}\text { [-21M13]-TGAGTCTTAGCTTCATTACAGA } \\
\text { [M13-Rev]-TAGGAGAGAAATCACTGCAAC }\end{array}$ & 21 & \\
\hline$U$ & $\begin{array}{l}\text { [-21M13]-TTTTTCTCTCCCCCTCTTCC } \\
\text { [M13-Rev]-TTGTAATAGTAGCTGTACTTCC }\end{array}$ & $22+23$ & \\
\hline V & $\begin{array}{l}\text { [-21M13]-TCCTTTGCGGCGCTAGGGTG } \\
\text { [M13-Rev]-TTGGCTCGGCGTGCTTTTGG }\end{array}$ & & $-48 \_554$ \\
\hline W & $\begin{array}{l}\text { [-21M13]-CCAGCTGCCTCTTATGGAAG } \\
\text { [M13-Rev]-AGCACACAGGCCTTCTCATC }\end{array}$ & & 484_1151 \\
\hline$x$ & $\begin{array}{l}\text { [-21M13]-GATGTCAGAGCCACTAGATC } \\
\text { [M13-Rev]-ACTCCTCCCAAAGAGCTCAGC }\end{array}$ & & 1080_1676 \\
\hline Y & $\begin{array}{l}\text { [-21M13]-AAGTCCTTCTAGATCCTATGG } \\
\text { [M13-Rev]-GCAGGTCAAGATCGGTGAAC }\end{array}$ & & 1586_2308 \\
\hline Z & [-21M13]-TCAGCCTCCTAATCAGGAAC & & 2211_2866 \\
\hline
\end{tabular}


2749_3388

3315_3910

RFLP CCTGGGTTGGGACAAGATCG [M13-Rev]-ATCGATACAGTGGTTCTTCTGGGAG

${ }^{1}$ All forward and reverse primers were tagged with a -21M13 (5'-GTAAAACGACGGCCAGT3') sequence or M13rev (5'-CAGGAAACAGCTATGACC-3') sequence.

Supplemental Table S2. Primer sets used for PEX2 mutation analysis.

\begin{tabular}{|c|c|c|}
\hline Amplicon & Sequence $\left(5^{\prime} \rightarrow 3^{\prime}\right)^{1}$ & Exons \\
\hline$A$ & $\begin{array}{l}\text { [M13-Rev]-TCAGAGACAGAGTTCTTCCG } \\
\text { [-21M13]-CAGGAAGCCAATAAACAGGG }\end{array}$ & 1 \\
\hline$B$ & $\begin{array}{l}\text { [M13-Rev]-ACTGAAGGCTCAGATGGTTG } \\
\text { [-21M13]-TGGTCTTCACCATCACAGTC }\end{array}$ & 2 \\
\hline C & $\begin{array}{l}\text { [M13-Rev]-TTAGAACACTGGCAGTGTGG } \\
\text { [-21M13]-ATGCTTCTCACCATAAATGCC }\end{array}$ & 3 \\
\hline D & $\begin{array}{l}\text { [M13-Rev]-AAACGCTCATCGCCTATGTG } \\
\text { [-21M13]-GTTGCAAACTTTCCCCTCTG }\end{array}$ & $4 \mathrm{~A}$ \\
\hline$E$ & $\begin{array}{l}\text { [M13-Rev]-TGGGAAAGTCAAGCAGTGTG } \\
\text { [-21M13]-TCCTCAAAGGAAGCAATTTTAG }\end{array}$ & 4B \\
\hline
\end{tabular}

${ }^{1}$ All forward and reverse primers were tagged with a -21M13 (5'-GTAAAACGACGGCCAGT3') sequence or M13rev (5'-CAGGAAACAGCTATGACC-3') sequence.

Supplemental Table S3. Primer sets used for PEX3 mutation analysis.

\begin{tabular}{|c|c|c|}
\hline Amplicon & Sequence $\left(5^{\prime} \rightarrow 3^{\prime}\right)^{1}$ & Regions of cDNA \\
\hline \multirow[t]{2}{*}{$A$} & [-21M13]- CTCACCCCTAGTCAGCCCAC & $-17 \_505$ \\
\hline & [M13-Rev]- CCATCTCCAAGTAGGTGCTG & \\
\hline \multirow[t]{2}{*}{ B } & [-21M13]- CTGGATAATGCAGCAGTTGG & 424_903 \\
\hline & [M13-Rev]- TGTTGCAGGTCCTGTTCAGTA & \\
\hline \multirow[t]{2}{*}{ C } & [-21M13]- ATGCCAGATGAAGAAACTCC & $715 \_1123+186$ \\
\hline & [M13-Rev]- TGCCCACAAAAACTGGTCTG & \\
\hline
\end{tabular}

${ }^{1}$ All forward and reverse primers were tagged with a -21M13 (5'-GTAAAACGACGGCCAGT3') sequence or M13rev (5'-CAGGAAACAGCTATGACC-3') sequence.

Supplemental Table S4. Primer sets used for PEX5 mutation analysis

\begin{tabular}{|c|c|c|}
\hline Amplicon & Sequence $\left(5^{\prime} \rightarrow 3^{\prime}\right)^{1}$ & Exons \\
\hline A & $\begin{array}{l}\text { [-21M13]-ACGGGCAGAGTTGTGGATG } \\
\text { [M13-Rev]-ATTGAA ATACGGGTGAACTAAG }\end{array}$ & $1+2$ \\
\hline B & $\begin{array}{l}\text { [-21M13]-AGCCTATGGGTTCATTTCATC } \\
\text { [M13-Rev]-AGAATTCTGTCCCATAGAAGC }\end{array}$ & $3+4$ \\
\hline C & $\begin{array}{l}\text { [-21M13]-TCAGTTGAATATGGGCATCTC } \\
\text { [M13-Rev]-TGTCCATACTCCTTTCAC }\end{array}$ & 5 \\
\hline D & $\begin{array}{l}\text { [-21M13]-ACAGGAACTGTCATTGTCATG } \\
\text { [M13-Rev]-CAGGAACGAAGAGACCTAAG }\end{array}$ & 6 \\
\hline
\end{tabular}




\begin{tabular}{|c|c|c|}
\hline$E$ & [-21M13]-TGGAAGTCCTTTCCCAAGTG & $7+8$ \\
\hline & $\begin{array}{l}\text { [-21M13]-TGAAATTCAAGAACTGCTGCC } \\
\text { [M13-Rev]-GAAGGAAGTTCTGGAACCTG }\end{array}$ & 9 \\
\hline & $\begin{array}{l}\text { [-21M13]-CTGCCTGCTGGTTGTCATC } \\
\text { [M13-Rev]-AAGACAAGGATCCAGGTCTG }\end{array}$ & $10+11$ \\
\hline & $\begin{array}{l}\text { [-21M13]-AGCTTGGCTTGGATCCCAG } \\
\text { [M13-Rev]-ACAGGCATGCACCATCAAAC }\end{array}$ & $12+13$ \\
\hline & $\begin{array}{l}\text { [-21M13]-CCTGGAGTAATGTGCAGAG } \\
\text { [M13-Rev]-GTACCGCTTATGGTCATCAG }\end{array}$ & $14+15$ \\
\hline
\end{tabular}

${ }^{1}$ All forward and reverse primers were tagged with a -21M13 (5'-GTAAAACGACGGCCAGT3') sequence or M13rev (5'-CAGGAAACAGCTATGACC-3') sequence.

Supplemental Table S5. Primer sets used for PEX10 mutation analysis.

\begin{tabular}{|c|c|c|}
\hline Amplicon & Sequence $\left(5^{\prime} \rightarrow 3^{\prime}\right)^{1}$ & Exons \\
\hline \multirow[t]{2}{*}{ A } & [-21M13]-GCTGCGCTGGTTCGGACT & 1 \\
\hline & [M13-Rev]-GGTGCCCCGCACATCCC & \\
\hline \multirow[t]{2}{*}{ B } & [-21M13]-GGAGACAGAAGCAGAGAGG & 2 \\
\hline & [M13-Rev]-CAGCACTGTGACTCACTGG & \\
\hline \multirow[t]{2}{*}{$\mathrm{C}$} & [-21M13]-CTCAAGGGCGACAAGATGG & 3 \\
\hline & [M13-Rev]-CTGGATGTAGAACCCTGTTG & \\
\hline \multirow[t]{2}{*}{$\mathrm{D}$} & [-21M13]-GTTTCTGCCGGGCACTCC & 4 and 5 \\
\hline & [M13-Rev]-AACTGGAGGGTGCTCAGAG & \\
\hline \multirow[t]{2}{*}{ E } & [-21M13]-CACACCCTGAGCCCTACG & 6 \\
\hline & [M13-Rev]-AAGCGCAGCCAGGGACAG & \\
\hline
\end{tabular}

${ }^{1}$ All forward and reverse primers were tagged with a -21M13 (5'-GTAAAACGACGGCCAGT3') sequence or M13rev (5'-CAGGAAACAGCTATGACC-3') sequence.

Supplemental Table S6. Primer sets used for PEX12 mutation analysis.

\begin{tabular}{clc}
\hline Amplicon & Sequence $\left(\mathbf{5}^{\prime} \rightarrow \mathbf{3}^{\prime}\right)^{\mathbf{1}}$ & Exons \\
\hline A & {$[-21$ M13]-TGAGCACCCATCTGATACTC } & 1 \\
& {$[$ M13-Rev]-CGCTAGGCTACCAAATAAGC } & \\
B & {$[-21$ M13]-TGTGTCATGGAATGAATTTCAC } & 2 \\
& {$[$ M13-Rev]-GGGATACGATTTTCGAATTTAC } & \\
C & {$[-21$ M13]-GGAGATAGTACCAGTCTACC } & 3 \\
& {$[$ M13-Rev]-TACCATGCTGAAACCAGCTC } & \\
\hline
\end{tabular}

${ }^{1}$ All forward and reverse primers were tagged with a -21M13 (5'-GTAAAACGACGGCCAGT3') sequence or M13rev (5'-CAGGAAACAGCTATGACC-3') sequence.

Supplemental Table S7. Primer sets used for PEX13 mutation analysis

\begin{tabular}{llc}
\hline Amplicon & Sequence $\left(\mathbf{5}^{\prime} \rightarrow \mathbf{3}^{\prime}\right)^{\mathbf{1}}$ & Exons \\
\hline A & {$[-21 \mathrm{M} 13]-C T A C A A A T T A G T G G C A T C C T C$} & 1 \\
& {$[$ M13-Rev]-GTGAGACACTAAAGTCCCCAC } & \\
B & {$[-21 M 13]-A G C A C C A G G T A T A T A G G A G A T G$} & 2 \\
& {$[$ M13-Rev]-TTGCTATATATTCCTCTGCCAG } &
\end{tabular}


D [M13-Rev]-TTTTGTGTGGGGATTAACAG [-21M13]-GTTGGACCTCCAAAGTTATTG [M13-Rev]-TATTTCTAGCAGCAAAACACC

${ }^{1}$ All forward and reverse primers were tagged with a -21M13 (5'-GTAAAACGACGGCCAGT3') sequence or M13rev (5'-CAGGAAACAGCTATGACC-3') sequence.

Supplemental Table S8. Primer sets used for PEX14 mutation analysis

\begin{tabular}{|c|c|c|}
\hline Amplicon & Sequence $\left(5^{\prime} \rightarrow 3^{\prime}\right)^{1}$ & Exons \\
\hline \multirow[t]{2}{*}{ A } & [-21M13]-TTAACGGAAACTATGCAAGG & 1 \\
\hline & [M13-Rev]-AAGGTGACCACAGATGAAGAG & \\
\hline \multirow[t]{2}{*}{ B } & [-21M13]-GACAAGTGAACCCAGAAACAG & 2 \\
\hline & [M13-Rev]-CAGAACCATAGGAACAGAAGG & \\
\hline \multirow[t]{2}{*}{ C } & [-21M13]-TACAGGAAGCCAGTGAAGAC & 3 \\
\hline & [M13-Rev]-GAGTGGGCAGCTCTAGGAAG & \\
\hline \multirow[t]{2}{*}{ D } & [-21M13]-AAAGCAGCAATAAACTCAAGG & 4 \\
\hline & [M13-Rev]-CTCCTGGTTTGCTAAGTCTGG & \\
\hline \multirow[t]{2}{*}{$\mathrm{E}$} & [-21M13]-ТTCТААСССТССТССТСТТС & 5 \\
\hline & [M13-Rev]- TCCCATTTTACAGACCAGAG & \\
\hline \multirow[t]{2}{*}{$\mathrm{F}$} & [-21M13]-TTTATGGTGTTTGCTTAGGG & 6 \\
\hline & [M13-Rev]-CTGTGAGGGGTGACTTGATG & \\
\hline \multirow[t]{2}{*}{ G } & [-21M13]-CCAGAGTGCAGATAAATTAG & 7 \\
\hline & [M13-Rev]-GTTGGGAGGTGACATAGAGAG & \\
\hline \multirow[t]{2}{*}{$\mathrm{H}$} & [-21M13]-ATCAGATGTCCAAACAGAGC & 8 \\
\hline & [M13-Rev]-TGGGGAATGAAGAGAGAAGC & \\
\hline \multirow[t]{2}{*}{ I } & [-21M13]-TCCTGAATGCCGCCACCAAC & 9 \\
\hline & [M13-Rev]-CAGGTGGACAGAAGTGTGAC & \\
\hline
\end{tabular}

${ }^{1}$ All forward and reverse primers were tagged with a -21M13 (5'-GTAAAACGACGGCCAGT3') sequence or M13rev (5'-CAGGAAACAGCTATGACC-3') sequence.

Supplemental Table S9. Primer sets used for PEX16 mutation analysis.

\begin{tabular}{|c|c|c|}
\hline Amplicon & Sequence $\left(5^{\prime} \rightarrow 3^{\prime}\right)^{1}$ & Exons \\
\hline \multirow[t]{2}{*}{ A } & [-21M13]-GAAGCAGGAAGGAGGGCG & 1 and 2 \\
\hline & [M13-Rev]-ATTCAGTCATAGCACAAGGTG & \\
\hline \multirow[t]{2}{*}{ B } & [-21M13]-TGTGAGATCATGTTGGGGAG & 3 \\
\hline & [M13-Rev]-CTAAGATGGGAATACTCACAC & \\
\hline \multirow[t]{2}{*}{$\mathrm{C}$} & [-21M13]-GTCAGAGAAGCTCCCTCCTAG & 4 and 5 \\
\hline & [M13-Rev]-TACTGTATTCATGCTGGTTGG & \\
\hline \multirow[t]{2}{*}{$\mathrm{D}$} & [-21M13]-CCTGCTTGTAGTTCCCTTGAC & 6,7 and 8 \\
\hline & [M13-Rev]-ATTATAGCAGAAAGCCCAGTG & \\
\hline \multirow[t]{2}{*}{$\mathrm{E}$} & [-21M13]-ACATAGGCGGGGTGGCAG & 9 \\
\hline & [M13-Rev]-CCCGGACAACACACAGTGC & \\
\hline $\mathrm{F}$ & [-21M13]-GCACGGTGGTCAGTGAAGG & 10 and 11 \\
\hline
\end{tabular}


[M13-Rev]-TATGGCTGCCGAGGCGAG ${ }^{1}$ All forward and reverse primers were tagged with a -21M13 (5'-GTAAAACGACGGCCAGT-
$\left.3^{\prime}\right)$ sequence or M13rev (5'-CAGGAAACAGCTATGACC-3') sequence.

Supplemental Table S10. Primer sets used for PEX19 mutation analysis

\begin{tabular}{|c|c|c|}
\hline Amplicon & Sequence $\left(5^{\prime} \rightarrow 3^{\prime}\right)^{1}$ & Exons \\
\hline \multirow[t]{2}{*}{ A } & [-21M13]-TCCGCACTGGTCAACAATAC & 1 \\
\hline & [M13-Rev]-TATCATGAAACGCCGTCCTG & \\
\hline \multirow[t]{2}{*}{ B } & [-21M13]-AGGAGGAAAATTGAGGAAAG & 2 \\
\hline & [M13-Rev]-CCAATCCAACCATTTAAACC & \\
\hline \multirow[t]{2}{*}{ C } & [-21M13]-TTAAATGGTTGGATTGGTATGC & 3 \\
\hline & [M13-Rev]-TCCCATCCTTTCTCTCATTG & \\
\hline \multirow[t]{2}{*}{$\mathrm{D}$} & [-21M13]-CATAGGGTTTTCCAAGATTG & 4 and 5 \\
\hline & [M13-Rev]-CCTGCCTCAAATAAATAAAG & \\
\hline \multirow[t]{2}{*}{ E } & [-21M13]-GTTTTTCTACGTCCCTTTCC & 6,7 and 8 \\
\hline & [M13-Rev]-CATAGCTGGGACTCAGAGAG & \\
\hline
\end{tabular}

${ }^{1}$ All forward and reverse primers were tagged with a -21M13 (5'-GTAAAACGACGGCCAGT3') sequence or M13rev (5'-CAGGAAACAGCTATGACC-3') sequence.

Supplemental Table S11. Primer sets used for PEX26 mutation analysis.

\begin{tabular}{|c|c|c|}
\hline Amplicon & Sequence $\left(5^{\prime} \rightarrow 3^{\prime}\right)^{1}$ & Exons \\
\hline$A$ & $\begin{array}{l}\text { [-21M13]-AGCTAGGGCCAGGTATTCC } \\
\text { [M13-Rev]-TGATGAAAGCGAGGTGTAAAG }\end{array}$ & 1 \\
\hline$B$ & $\begin{array}{l}\text { [-21M13]-AACGTTGAGCAACAGCTGAC } \\
\text { [M13-Rev]-GATCTGGAGGGCAATAGTAG }\end{array}$ & 2 \\
\hline C & $\begin{array}{l}\text { [-21M13]-GTTAGTGATGGGTGTGTCGT } \\
\text { [M13-Rev]-TTCCACTGCCAACTTCAGAG }\end{array}$ & 3 \\
\hline D & $\begin{array}{l}\text { [-21M13]-TCTCGATCTCCTGACCTTGT } \\
\text { [M13-Rev]-CTAGCAATTCCTCCTTGTGG }\end{array}$ & 4 \\
\hline$E$ & $\begin{array}{l}\text { [-21M13]-AGCTGAACACAGACTGCACT } \\
\text { [M13-Rev]-CACATCATCTACCGCGACC }\end{array}$ & 5 \\
\hline
\end{tabular}

${ }^{1}$ All forward and reverse primers were tagged with a -21M13 (5'-GTAAAACGACGGCCAGT3') sequence or M13rev (5'-CAGGAAACAGCTATGACC-3') sequence. 